\title{
Targeting the PDGF signaling pathway in tumor treatment
}

\author{
Carl-Henrik Heldin
}

\begin{abstract}
Platelet-derived growth factor (PDGF) isoforms and PDGF receptors have important functions in the regulation of growth and survival of certain cell types during embryonal development and e.g. tissue repair in the adult. Overactivity of PDGF receptor signaling, by overexpression or mutational events, may drive tumor cell growth. In addition, pericytes of the vasculature and fibroblasts and myofibroblasts of the stroma of solid tumors express PDGF receptors, and PDGF stimulation of such cells promotes tumorigenesis. Inhibition of PDGF receptor signaling has proven to useful for the treatment of patients with certain rare tumors. Whether treatment with PDGF/PDGF receptor antagonists will be beneficial for more common malignancies is the subject for ongoing studies.
\end{abstract}

\section{Introduction}

Platelet-derived growth factor (PDGF) isoforms stimulate growth, survival and motility of mesenchymal cells and certain other cell types [1,2]. They have important functions during embryonal development and in the control of tissue homeostasis in the adult. Overactivity of PDGF signaling is associated with the development of certain malignant diseases, as well as non-malignant diseases characterized by excessive cell proliferation. The involvement of PDGF overactivity in non-malignant diseases has been discussed in a recent review [3]. The present review will focus on the role of PDGF signaling in tumor development, and on the use of PDGF antagonists in tumor treatment.

\section{PDGF isoforms}

The PDGF family consists of disulphide-bonded homodimers of A-, B-, C- and D-polypeptide chains, and the heterodimer PDGF-AB. The PDGF isoforms are synthesized as precursor molecules. PDGF-AA, $-\mathrm{AB}$ and $-\mathrm{BB}$ are cleaved already inside the producer cells in secretory vesicles. In contrast, PDGF-CC and -DD are secreted as inactive precursor molecules; $\mathrm{N}$-terminal CUB-domains need to be cleaved off to activate the growth factors. This cleavage serves an important regulatory role, and is performed by tissue-type plasminogen activator (tPA) or

Correspondence: C-H.Heldin@LICR.uu.se

Ludwig Institute for Cancer Research, Science for life laboratory, Uppsala University, Box 595SE-751 24 Uppsala, Sweden plasmin in the case of PDGF-CC, and by urokinase-type PA (uPA) or matriptase (MT-Sp1) in the case of PDGFDD [4-7] (Figure 1).

\section{Signaling via PDGF receptors}

PDGF isoforms exert their cellular effects by binding to $\alpha-$ and $\beta$-tyrosine kinase receptors (PDGFR $\alpha$ and PDGFR $\beta$, respectively). The two PDGF receptors are structurally similar and consist of extracellular domains with five immunoglobulin (Ig) - like domains and intracellular parts with kinase domains which contain characteristic inserts of about 100 amino acid residues without homology to kinases. Ligand binding occurs mainly to Ig-like domains 2 and 3, and causes dimerization of the receptors, which is further stabilized by direct receptor-receptor interactions involving Ig-like domain $4[8,9]$. The dimerization is a key event in activation since it brings the intracellular parts of the receptors close to each other promoting autophosphorylation in trans between the receptors. The PDGF polypeptide chains bind to the receptors with different affinities. Thus, PDGF-AA, $-\mathrm{AB},-\mathrm{BB}$ and -CC induce $\alpha \alpha$ receptor homodimers, PDGF-BB and PDGF-DD $\beta \beta$ receptor homodimers, and PDGF-AB, $-\mathrm{BB},-\mathrm{CC}$ and $-\mathrm{DD} \alpha \beta$ receptor heterodimers Figure 1; [2].

The autophosphorylation serves two important functions. First, it changes the conformation of the intracellular part of the receptor so that the kinase is activated. There is no 3-dimensional structure yet for PDGF receptors, so precise information about mechanisms that control the kinase is not available. However, it is likely that in the resting 


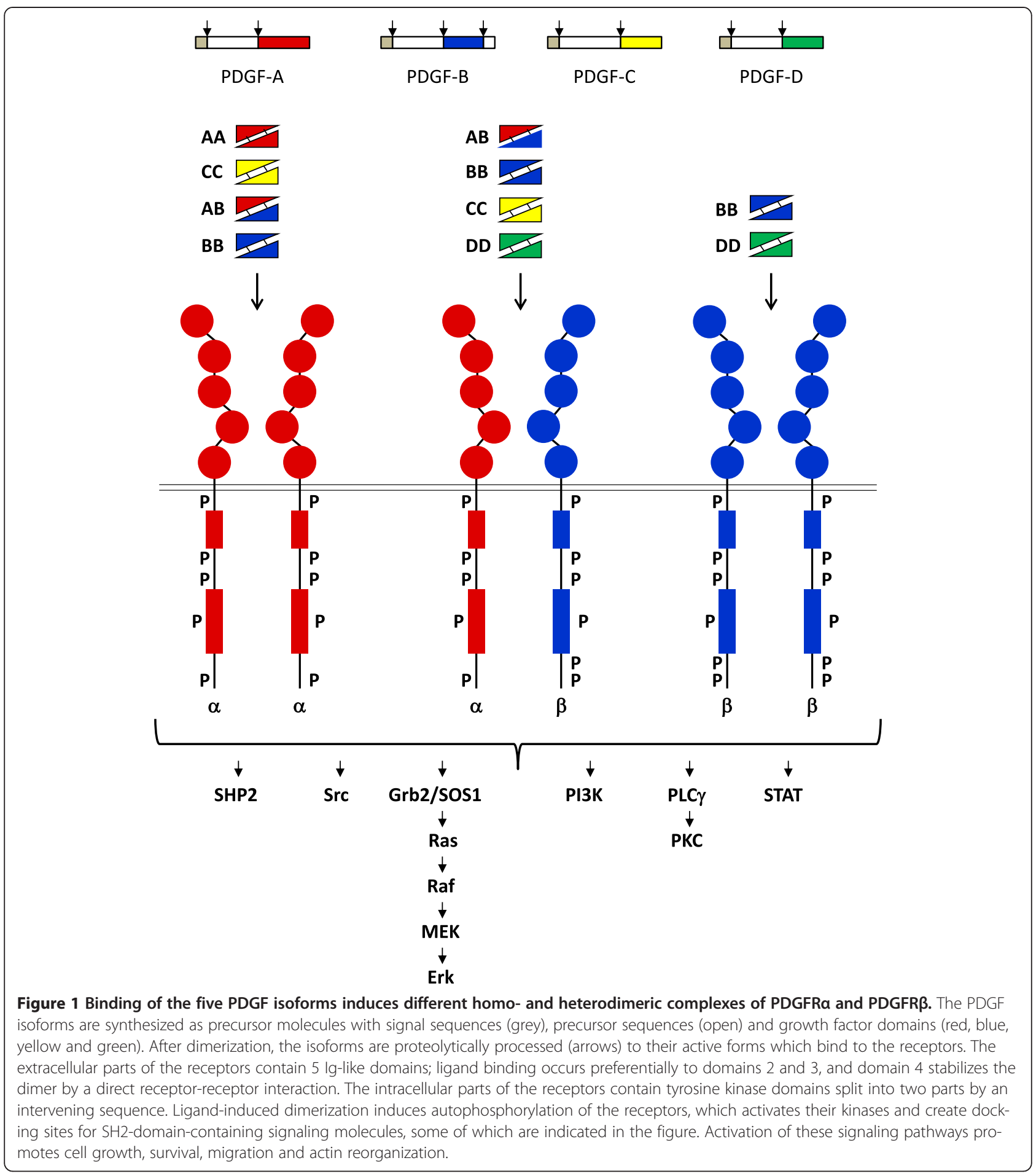

state, the kinase is kept inactive by at least three mechanisms: $i$ ) The activation loop in the kinase domain is likely to be folded over the catalytic cleft; autophosphorylation of a conserved tyrosine residue in this region causes the loop to move away from the active site [10]. ii) The juxtamembrane part of the receptor is likely to be folded in a loop which restricts the access to the active site; autophosphorylation of two tyrosine residues in this region changes the conformation and enhances the kinase activity [11]. iii) The C-terminal tail of the receptor is most likely folded over the kinase domain; autophosphorylation of two C-terminally located tyrosine residues relieves the kinase of this inhibition [12]. Similar regulatory mechanisms have been observed in the 
structurally related colony stimulating factor-1 receptor (CSF1R) and FLT3.

Second, autophosphorylation creates docking sites for SH2-domain-containing signaling molecules. The $\alpha$ and $\beta$-receptors contain 10 and 11 known autophosphorylated tyrosine residues, respectively [13]. About 10 different families of SH2-domain-containing molecules have been shown to selectively bind to different phosphorylated residues in the PDGF receptors. These include signaling molecules with intrinsic enzymatic activities, such as tyrosine kinases of the Src family, the SHP-2 tyrosine phosphatase, phospholipase C- $\gamma$ (PLC$\gamma)$ and the GTPase activating protein (GAP) for Ras. Moreover, the receptors bind and activate signal transducers and activators of transcription (STATs), which after activation are translocated to the nucleus where they act as transcription factors. Finally, the receptors bind adaptor molecules which lack intrinsic enzymatic activities, but can form complexes with other signaling molecules. Examples include the regulatory subunit p85 of the phosphatidylinositol 3'-kinase (PI3K), which forms complex with the p110 catalytic subunit, and Grb2 which binds the nucleotide exchange molecule SOS1, activating Ras and the Erk MAP-kinase pathway (Figure 1). In addition, the PDGF receptors bind other adaptors, e.g. Shc, Nck, Crk and GAB, which mediate interactions with a plethora of different downstream signaling molecules. The activation of these signaling pathways leads to cell proliferation and survival, as well as to actin reorganization and cell migration. The extensive cross-talk between the different signaling pathways makes it difficult to assign individual pathways to specific responses; in a cell-type- and context-dependent manner, several signaling pathways contribute to each of the cellular responses.

\section{Modulation and termination of PDGF receptor signaling} Signaling via PDGF receptors is carefully controlled and modulated. In the early phase of signaling different mechanisms assure that the signal rapidly reaches sufficient strength. For instance, in PDGF stimulated cells reactive oxygen species are produced in a PI3-kinasedependent pathway, which inhibit tyrosine phosphatases by reacting with a cysteine residue in their active site $[14,15]$. Another mechanism that amplifies the signaling is the ubiquitination and degradation of MAP-kinase phosphatase 3, which dephosphorylates and inactivates Erk MAP-kinase; removal of this phosphatase enhances Erk MAP-kinase activation [16].

There are also mechanisms that negatively modulate PDGF signaling. One example is the docking of RasGAP to the activated PDGFR $\beta$; this counteracts the activation of Ras which occurs by the simultaneous docking of the Grb2-SOS1 complex [17]. Interestingly, PDGFR $\alpha$ does not bind Ras-GAP and therefore activates Erk MAP-kinase more efficiently than PDGFR $\beta$ [18].

Negative modulatory effects are also exerted by tyrosine phosphatases which dephosphorylate and inactivate PDGF receptors. Examples of such phosphatases include PTP1B [19], TC-PTP [20] and PTPRJ/DEP-1 [21,22]. In addition, the tyrosine phosphatase SHP-2 binds to PDGF receptors and dephosphorylates the receptors and their substrates. However, SHP-2 also positively modulates signaling, e.g. via dephosphorylation of a C-terminal inhibitory phosphorylation site in Src family members, thereby activating them [23], or by acting as an adaptor for binding of the Grb2-SOS1 complex, thus promoting Ras activation [24].

Other mechanisms of modulation of PDGF receptor signaling are exerted by interactions with other cell surface receptors. Thus, PDGF receptor interaction with other tyrosine kinase receptors, such as the EGF receptor [25], has been observed. Moreover, PDGF receptors have been shown to interact with non-kinase receptors; thus, integrins [26] and the low density lipoprotein receptor-related protein [27-29] enhance signaling, whereas interaction with the hyaluronan receptor CD44 suppresses signaling [30].

Activation of PDGF receptors triggers internalization of the receptors in a clathrin- and dynamin-dependent manner. Internalization is promoted by ubiquitination of the receptors by the ubiquitin ligase $\mathrm{Cbl}$ [31]. Signaling continues in endosomes [32] until the receptors are degraded in proteasomes and lysosomes. Alternatively, receptors can be sorted to recycling vesicles whereby they reappear at the plasma membrane where they can signal again. One mechanism which promotes sorting of receptors to recycling is exerted by activation of $\mathrm{PLC} \gamma$ and the downstream protein kinase C (PKC) [33], another involves PI3-kinase-mediated uptake of the receptor via an alternative internalization route, i.e. macropinocytosis [34]. Increased receptor recycling is accompanied by an increased amplitude and duration of signaling.

\section{Normal function of PDGF isoforms and receptors}

The physiological functions of PDGF have been analyzed using mice with the genes for PDGF isoforms or receptors knocked-out. These studies have elucidated important roles for PDGF isoforms in the development of mesenchymal cell types of different organs reviewed in [2]. Often PDGF isoforms are produced by epithelial or endothelial cells and act in a paracrine manner on nearby mesenchymal cells, such as fibroblasts, pericytes and smooth muscle cells. Thus, signaling via PDGFR $\alpha$ is important for the development of the facial skeleton, hair follicles, spermatogenesis oligodendrocytes and astrocytes [35], as well as for the development of the lung [36] and intestinal villi [37]. Signaling via PDGFR $\beta$ is 
important for the development of blood vessels, kidneys [38-41] and white adipocytes [42].

In the adult, PDGF stimulates wound healing [43]. It also regulates the intestinal fluid pressure in tissues and thereby counteracts edema formation [44].

\section{PDGF signaling antagonists}

The involvement of PDGF overactivity in malignant diseases (see further below), as well as certain nonmalignant diseases [3], has led to the development of different types of antagonists of PDGF signaling that now are under preclinical and clinical evaluation.

The developed inhibitors include antibodies, DNA aptamers or soluble extracellular parts of the receptors that bind PDGF isoforms and thus prevent their binding to signaling receptors $[45,46]$. Alternatively, antibodies or other binders can target the receptors and prevent their activation or promote their degradation [47-49]. These types of antagonists have the advantage of being reasonably specific, however, they are expensive and cumbersome to administer. Another type of antagonists are low molecular inhibitors of the receptor kinases (Table 1). Several potent inhibitors of PDGF receptor kinases have been developed, including imatinib, sunitinib, sorafenib, pazopanib and nilotinib. None of these inhibitors are specific; they all have their characteristic profiles of inhibition of different other kinases. Thus, imatinib, in addition to inhibiting PDGF receptor kinases, inhibits the stem cell receptor (Kit) and Abl kinases, and sunitinib inhibits vascular endothelial cell growth factor (VEGF) receptors and Flt3; sorafenib has an inhibitory profile similar to sunitinib, but also inhibits the serine/

Table 1 Characteristics of PDGF receptor kinase inhibitors

\begin{tabular}{lll}
\hline Inhibitor & Primary targets & Secondary targets \\
\hline Imatinib & Abl, PDGFR, Kit & Raf \\
Sunitinib & PDGFR, VEGFR, Kit, Flt3 & \\
Sorafenib & Raf, VEGFR, PDGFR, Kit, Flt3 & FGFR \\
Pazopanib & VEGFR, PDGFR, Kit & FGFR \\
Nilotinib & Kit, Abl, PDGFR & \\
Cediranib & VEGFR, Kit, PDGFR & FGFR \\
Motesanib & VEGFR, Kit & PDGFR, Ret \\
Axitinib & VEGFR & PDGFR, Kit \\
Linifenib & VEGFR, Kit & PDGFR \\
Dasatinib & Abl, Src & PDGFR, Kit \\
Quizartinib & FLT3 & Kit, PDGFR, Ret, CSF1R \\
Ponatinib & Ret, Abl & PDGFR, VEGFR \\
\hline
\end{tabular}

The table summarizes the specificities of some kinase inhibitors targeting PDGF receptors. The $K_{d}: S$ of the different members of the PDGFR, VEGFR and FGFR families are often similar and are lumped together, for simplicity. As primary targets are listed the kinases that are inhibited at the lowest concentrations (regardless of absolute concentrations). As secondary targets are listed kinases that are inhibited by about 10-fold higher inhibitor concentrations. For references, see [3,50-54]. threonine kinase Raf. Although the lack of specificity contributes to side effects and can be seen as a disadvantage, experience has shown that it is often advantageous to hit more than one kinase in tumor treatment.

\section{PDGF signaling in malignant diseases}

There are several observations supporting the notion that overactivity of PDGF signaling can drive tumorigenesis [55]. In certain tumors, PDGF or PDGF receptor genes are mutated, alternatively, their expressions are increased. Thus, in the rare skin tumor dermatofibrosarcoma protuberance (DFSP), the gene encoding PDGF-B is fused to the gene encoding collagen $1 \mathrm{~A} 1[56,57]$. This leads to the production of large amounts of a fusion protein consisting of $\mathrm{N}$-terminal collagen sequence and $\mathrm{C}$ terminal PDGF-B sequence. After processing, a PDGFBB-like protein is released which stimulates the growth and survival of the producer fibroblasts in an autocrine manner [58].

The PDGF receptor genes have also been found to be mutated in certain malignancies. Point mutations in the PDGFR $\alpha$ gene occur in about $5 \%$ of gastrointestinal stromal tumors (GIST); these mutations lead to amino acid residue replacements in critical regions of the receptor causing activation of the kinase [59]. In GIST, similar mutations in the structurally related receptor Kit, is even more common. PDGF receptor genes have been found involved in gene rearrangements in certain leukemias [60]. Thus, the intracellular parts of both PDGFR $\alpha$ and PDGF $\beta$ genes have been found to be fused to different partner genes that encode molecules that can oligomerize; the combination of loss of regulatory sequences in the juxtamembrane and transmembrane parts of the receptors and their oligomerization activate the receptor kinases. Moreover, in 5-10\% of glioblastoma multiforme cases, the $\alpha$-receptor gene is amplified resulting in expression of a high number of receptors [61-63]. Amplification of PDGFR $\alpha$ has also been observed in oligodendrogliomas [64], esophageal squamous cell carcinoma [65], and artery intimal sarcomas [66,67]. This makes the cells susceptible to stimulation by lowered amounts of PDGF, or if the number of receptors become high enough, signaling may occur in a PDGF-independent manner. An activating deletion mutation in the PDGFR $\alpha$ gene has also been detected in a human glioblastoma [68].

During tumorigenesis, epithelial tumors may undergo epithelial-mesenchymal transition (EMT), which is associated with increased invasiveness and metastasis [69]. During EMT, PDGF receptor expression by the tumor cells increases, so that epithelial tumors that initially did not respond to PDGF may become responsive to PDGF stimulation [70]. The expression of PDGF isoforms are also part of the EMT program, which may enhance PDGF receptor signaling by autocrine stimulation. 
PDGF produced by tumor cells or non-tumorigenic cells, such as endothelial cells and macrophages, also acts on non-tumor cells in solid tumors. Thus, pericytes around blood vessels, and fibroblasts and myofibroblasts in the stroma, carry PDGF receptors and respond to PDGF. Pericytes are dependent on PDGF produced by endothelial cells and have an important role during angiogenesis [40]. PDGF stimulation of fibroblasts and myofibroblasts in the stroma contributes to the increased interstitial fluid pressure (IFP) in solid tumors. The increased IFP is an obstacle in chemotherapeutic treatment of tumors, since it decreases the transcapillar flow and decreases drug uptake reviewed by [71].

The fact that PDGF receptor signaling is often overactive in tumors has prompted attempts to treat patients with various malignancies with PDGF/PDGF receptor antagonists. During tumor progression, tumor cells acquire a number of mutations, some of which drive tumorigenesis. It has been observed that tumor cells often become "addicted" to the signaling pathways that are activated by mutational events, and that inhibition of such pathways induces apoptosis of the tumor cells [72]. On the other hand, after some time re-growth of the tumor often occurs, due to the appearance of various types of resistance mechanisms. The involvement of PDGF signaling in specific tumor types and the possible usefulness of PDGF antagonists in tumor treatment (Table 2), are discussed in the following sections. First, mechanisms operating in the tumor cells themselves are discussed; the involvement of PDGF stimulation in the stroma compartment is discussed in a later chapter.

\section{Brain tumors}

A clear demonstration that autocrine stimulation by PDGF can drive the development of glioblastoma multiforme (GBM) was the finding that simian sarcoma virus (SSV) induces brain tumors in marmoset monkeys [73]; the transforming oncogene of SSV, $\mathrm{v}$-sis, encodes a PDGF-B-like molecule [74,75]. In human material, increased expression of PDGF isoforms and PDGF receptors have been demonstrated in GBM cell lines [76,77] and in tumor tissue [78-84]. Notably, a malignancydependent increased expression was noticed where the $\alpha$-receptor was primarily expressed in the tumor cells, and the $\beta$-receptor in the stromal cells. Amplification of the PDGF $\alpha$-receptor has been demonstrated, but is not

Table 2 Use of PDGFR kinase inhibitors in clinical trials for different tumors

\begin{tabular}{|c|c|c|}
\hline Tumor type & Results of patient studies & Refs \\
\hline \multirow[t]{2}{*}{ Glioblastoma multifome } & Only limited effects of single agent treatment by imatinib in Phase II and Phase III studies. & {$[103,104]$} \\
\hline & No significant effect of imatinib treatment in combination with hydroxyurea. & {$[105,106,108]$} \\
\hline Chordoma & 1 PR and 35 SD out of 50 patients treated, were observed in a Phase II study. & [110] \\
\hline \multirow[t]{2}{*}{ Meningeoma } & No or only modest effect of imatinib as single agent or combined with hydroxyurea. & {$[111,112]$} \\
\hline & Among 9 patients preselected for PDGFR expression, 7 SD were noted. & [113] \\
\hline \multirow{2}{*}{$\begin{array}{l}\text { Dermatofibrosarcoma } \\
\text { protuberance }\end{array}$} & In a Phase II study, 4 CR and 4 PR out of 12 patients treated were recorded. & [126] \\
\hline & In other Phase II trials, PR was noticed in about half of the patients. & {$[117,127-130]$} \\
\hline $\begin{array}{l}\text { Gastrointestinal stromal } \\
\text { tumor }\end{array}$ & $\begin{array}{l}\text { Imatinib and other tyrosine kinase inhibitors against PDGFRa and Kit are used routinely in the clinic with } \\
\text { good results }\end{array}$ & [132-138] \\
\hline Soft tissue sarcoma & $\begin{array}{l}\text { In a Phase III study with } 369 \text { patients a median progression-free survival of } 4.6 \text { months was noted in pa- } \\
\text { tients treated with pazopanib compared with } 1.6 \text { months for untreated controls }\end{array}$ & [149] \\
\hline \multirow[t]{2}{*}{ Osteosarcoma } & No advantage of treatment with imatinib as single agent. & [141] \\
\hline & Some effect of imatinib in combination with everolimus in treatment of synovial sarcoma. & [142] \\
\hline $\begin{array}{l}\text { Chronic } \\
\text { myeloproliferative } \\
\text { diseases }\end{array}$ & Patients with CMML with rearrangement of PDGFRß responded to imatinib. & [168] \\
\hline \multirow{2}{*}{$\begin{array}{l}\text { Hypereosinophilic } \\
\text { syndrome }\end{array}$} & Patients with HES responded to imatinib. & [169-172] \\
\hline & Patients who developed resistance to imatinib responded to nilotinib or sorafenib. & {$[174,175]$} \\
\hline \multirow[t]{2}{*}{ Prostate cancer } & $\begin{array}{l}\text { Out of } 44 \text { patients with hormone-refractory prostate cancer treated with sunitinib, } 1 \text { had PR, } 3 \text { a decline in } \\
\text { prostate specific antigen of }>50 \% \text {, and } 9 \text { had a significant improvement in pain. }\end{array}$ & [181] \\
\hline & No increased survival upon treatment with imatinib. & {$[195,196]$} \\
\hline \multirow{2}{*}{$\begin{array}{l}\text { Non-small cell lung } \\
\text { cancer }\end{array}$} & Combination treatment with imatinib and docetaxel yielded 1 PR and 4 SD out of 20 treated patients. & [213] \\
\hline & 2 PR and 7 SD were observed after treatment of 18 patients with sunitinib. & [214] \\
\hline Neuroblastoma & $\begin{array}{l}\text { Little or no effect by imatinib as single agent treatment of children with relapsed or refractory } \\
\text { neuroblastoma. }\end{array}$ & [236] \\
\hline
\end{tabular}


as common as amplification of the EGF receptor [61]. Mutations in the PDGFR $\alpha$ gene, in the parts encoding the extracellular as well as the intracellular domains [85-88], have been observed; in addition, a fusion with the VEGFR2 gene has been found [89].

The importance of autocrine stimulation by PDGF has been verified in animal models, in which a retrovirus encoding PDGF-B was injected in newborn mice $[90,91]$. PDGF-induced transformation was found to be enhanced by mutations in certain tumor suppressor genes, such as Ink4/Arf, TP53 and PTEN [92-94]. In cells with Ink4a/Arf deficiency, PDGFR $\alpha$ promotes tumorigenesis via the SHP2/PI3K/Akt/mTOR pathway [95].

PDGF overexpression forces differentiation of glial cells to the oligodendrocyte lineage and promotes the development of highly malignant oligodendroglial tumors in mice [96-98]. The transforming efficiency of PDGF stimulation is illustrated by the fact that overexpression of PDGF-B in corpus callosum causes GBM also in adult rats [99]. Overexpression of the long isoforms of PDGF-A, which has a retention motif enhancing its autocrine stimulatory effect, was also found to efficiently promote GBM development [100].

Glioma stem cells preferentially express PDGFR $\beta$ and its activation promotes glioma stem cell self-renewal, suggesting that targeting of this receptor can be beneficial in treatment of glioma patients [101]. PDGF-B depletion completely abrogated the tumor initiating capacity of glioma stem cells [102].

Despite the finding that the PDGF receptor kinase inhibitor imatinib enhances the cytotoxicity of radiation in a mouse glioma model [103], only limited effects were recorded by imatinib treatment in Phase II clinical trials in glioblastoma patients [104,105]. Subsequent Phase II and Phase III studies explored the combination between imatinib and hydroxyurea in the treatment of recurrent glioblastoma, but no clinically meaningful antitumor effect was observed [106-108].

In addition to glioblastoma, PDGF overactivity has been implicated also in other types of brain tumors. PDGFR $\alpha$ and $\beta$ have been shown to be overexpressed in ependymoma of children and expression of PDGF $\alpha$ was found to correlate to poor prognosis [109].

Chordoma is a rare slow-growing tumor arising from remnants of the notochord, which often expresses PDGFR $\beta$. Following encouraging treatment results of occasional patients with imatinib [110], a Phase II clinical study was organized. Among 50 patients treated, one partial response and 35 patients with stable disease were recorded [111].

Meningeomas are mostly benign tumors with good prognosis that are treated with surgery, but some are inoperable and requires other treatment. Since meningiomas often express PDGF receptors, treatments of recurrent meningeomas with single-agent imatinib [112] or with imatinib plus hydroxyurea [113] have been tried; however, no or only modest effect was recorded. On the other hand, more encouraging results were obtained in a small study with preselected patients with recurrent meningeomas with expression of at least one of the PDGF receptors; whereas no complete or partial responses were seen, seven out of nine patients showed stable disease after imatinib treatment [114].

PDGF receptors, as well as c-Kit, have been found to be overexpressed and overactivated in peripheral and vestibular schwannomas [115]. Treatment of vestibular schwannoma cells [116] or other types of primary schwannoma cells [117], lacking the tumor suppressor NF2, with nilotinib inhibited the growth of the cells in vitro.

\section{Sarcomas}

Like in the case of glioblastomas, the normal counterpart cells of sarcomas express PDGF receptors. Overexpression of PDGF isoforms may then stimulate cell growth and survival in autocrine and paracrine manners. The clearest example that such mechanisms can drive tumorigenesis is the rare skin tumor DFSP, which is characterized by a gene rearrangement placing the collagen $1 \mathrm{~A} 1$ gene upstream of the PDGF-B gene [118]. This leads to the production of a fusion protein which is processed to a molecule similar to mature PDGF-BB and causes autocrine stimulation of growth $[57,58,119]$.

Inhibition of PDGF receptor signaling by the kinase inhibitor imatinib inhibits the growth and promotes apoptosis of DFSP cells $[120,121]$. Treatment with imatinib has also shown beneficial effects for individual patients with DFSP [122-126]. These encouraging findings prompted a multicenter Phase II trial; out of 12 patients with DFSP, 4 showed complete and 4 partial responses [127]. The median time to progression was 24 months [128]. Additional Phase II trials showed partial responses in about half of the cases; however, the response were rather short-lived whereafter resistance mechanisms occurred [118,129-131].

In about $5 \%$ of patients with GIST, PDGFR $\alpha$ is activated by point mutations [59]. Treatment with imatinib has been shown to improve the outcome for GIST patients [132-134]. Upon development of resistance to imatinib, other kinase inhibitors, such as sunitinib [135] and nilotinib [136-138] have shown efficacy.

PDGF and PDGF receptors are also expressed in other types of sarcomas. Early studies revealed that a human osteosarcoma cell line, U-2OS, secretes a PDGF-like growth factor and shows autocrine receptor activation by this factor [139]. Malignancy-dependent co-expression of PDGF and PDGF receptors have also been observed in biopsies of soft tissue sarcoma [140,141], osteosarcoma 
[142] and synovial sarcoma [143]. Nearly all cases of Ewing's sarcoma show the presence of the chimeric transcription factor EWS/ETS which causes upregulation of PDGF-C; treatment of a cell line from a Ewing's sarcoma with a PDGFR kinase inhibitor was shown to inhibit its anchorage-independent growth [144].

Whereas treatment of osteosarcoma patients with imatinib did not show any advantage as a single agent [142], the combination of the mTOR inhibitor everolimus and imatinib may be useful in the treatment of synovial sarcoma [143].

PDGFR $\alpha$ is selectively upregulated in rhabdomyosarcoma $[145,146]$, and PDGFR $\alpha$ expression is associated with poor prognosis $[147,148]$. Treatment with imatinib or a neutralizing PDGFR $\alpha$ antibody inhibited growth of alveolar rhabdomyosarcoma in a mouse model [146].

In a large randomized, double-blind, placebo-controlled Phase III trial, 369 patients with metastatic non-adipocytic soft tissue sarcoma who had failed on standard therapy, were subjected to treatment with pazopanib or not [149]. A median progression-free survival of 4.6 months and an overall survival of 12.5 months were recorded for the pazopanib treated patients, compared to 1.6 and 10.7 months, respectively for untreated patients. This study thus showed that treatment with pazopanib is of some advantage for these patients with sarcomas.

PDGF and PDGF receptors are also overexpressed in dog hemangiosarcoma, a malignant neoplasia of vascular endothelial cells [150]. Treatment of hemangiosarcoma in dogs with imatinib and dasatinib augmented the response to doxorubicin; however, dasatinib, which inhibits Src in addition to PDGF receptor kinases, was more efficient [151].

\section{Leukemias and lymphomas}

Activating mutations in the $A b l$ and $J A K 2$ genes, encoding tyrosine kinases, are common in myeloproliferative diseases; in some cases mutations are also seen in the PDGFR $\alpha$ and PDGFR $\beta$ genes [60].

In chronic monomyelocytic leukemia (CMML) the PDGFR $\beta$ gene has been found to be fused with the gene encoding the transcription factor TEL; the N-terminal of the fusion protein contains sequences from TEL which is followed by the intracellular part of the receptor containing the kinase domain [152] (Figure 2). There are also other fusion partners, including Rabaptin 5 [153], HIP1 [154] and H4 [155]. In a case of thrombocythemia, the tumor suppressor gene KANK1 was found to be fused with the PDGFR $\beta$ gene [156].

PDGFR $\alpha$ are also rearranged in certain malignancies. Thus, in hypereosinophilic syndrome (HES), the $\alpha$-receptor gene is fused to the FIP1L1 gene [157-159] (Figure 2). Activating point mutations in the PDGF $\alpha$-receptor have also been seen [160].

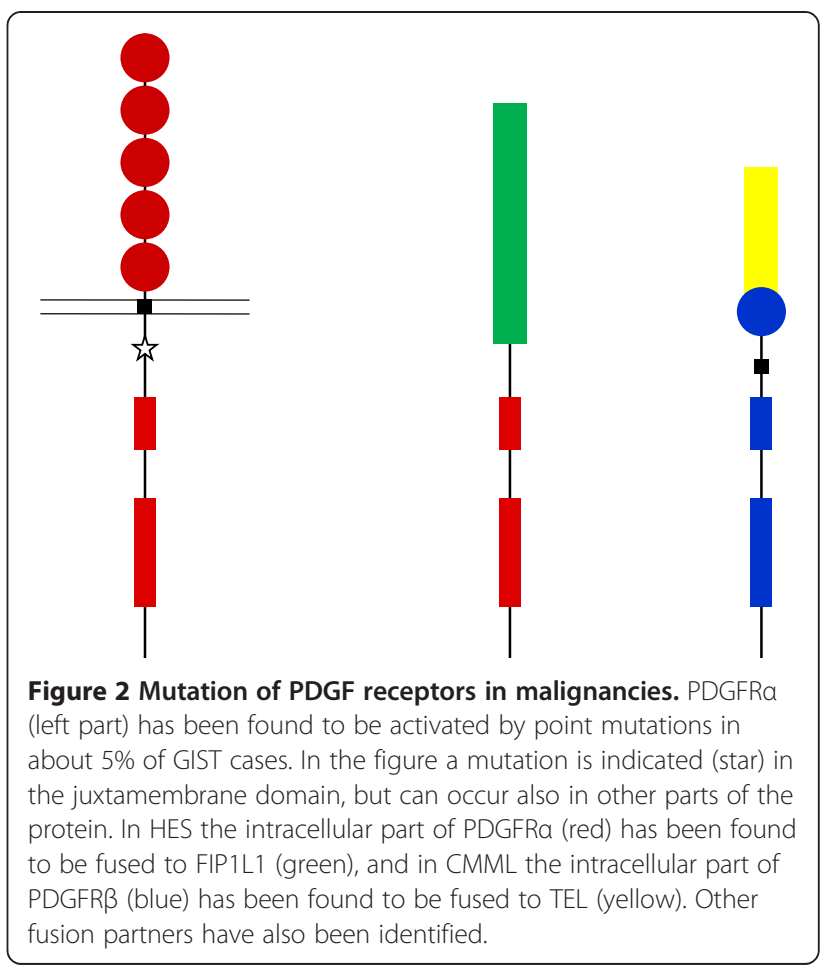

These proteins all have the ability to oligomerize and thus cause clustering of the receptor kinase; the juxtaposition of the kinase domains, as well as the loss of inhibitory transmembrane [161] and juxtamembrane [162] sequences, cause activation of the kinase. Moreover, escape of ubiquitin-mediated degradation causing accumulation of large amounts of the fusion proteins may also contribute to the transformation [163].

Activation of the PDGFR $\beta$ kinase through gene rearrangements leads to chronic myeologenous leukemia (CML) or CMML [152], whereas activation of the PDGFR $\alpha$ kinase causes HES or chronic eosinophilic leukemia [164-166]. Interestingly, activation of yet other tyrosine kinases is associated with other types of leukemia, i.e. activation of the FLT3 kinase with acute myelocytic leukemia (AML) or myelodysplastic syndrome, and activation of the Kit kinase with aggressive mastocytosis, myelodysplastic syndrome and AML for references see [166]. It is likely that these differences reflect differences in the activation of signaling pathways. FIP1L1-PDGFR $\alpha$ activates STAT5, PI3kinase and the Ras-Erk and p38 MAP-kinase pathways; particularly, the stronger activation of Erk and p38 MAPkinases by FIP1L1-PDGFR $\alpha$, compared to TEL-PDGFR $\beta$, could be linked to eosinophilic differentiation [167]. Both TEL-PDGFR $\alpha$ and FIP1L1-PDGFR $\alpha$ fusion proteins activate the transcription factors STAT1, 3 and 5, and nuclear factor- $\mathrm{kB}(\mathrm{NF} \mathrm{KB})$, and cause proliferation and differentiation towards the eosinophilic lineage [168].

Patients with CMML have been successfully treated with imatinib [169], as have patients with HES [170-173]. Point 
mutations conferring imatinib resistance have been described both for TEL-PDGFR $\beta$ [174] and FIP1L1-PDGFR $\alpha$ [157]. Other kinase inhibitors, such as nilotinib or sorafenib [175], or midostaurin (PKC412) [164], could inhibit some of the resistant kinase mutants, and offers alternative treatments [176]. Interestingly, only few cases of resistance due to point mutations in the PDGFR kinase domains have been reported, in contrast to the situation for the treatment of chronic myeloic leukemia in which such mutations in the kinase domain of Brc-Abl are very common; it has been suggested that this is because the PDGFR $\alpha$ kinase domain contains only few residues which can be exchanged resulting in interference with inhibitor binding, without loss of kinase activity [177].

Large granular lymphocyte leukemia results from the expansion of cytotoxic $\mathrm{T}$ cells or natural killer cells, cell types that have been shown to express PDGF receptors $[178,179]$. Together with stimulation by IL-15, autocrine stimulation by PDGF-BB drives the development of this rare leukemia, and a PDGF-BB neutralizing antibody was found to inhibit growth and survival of the leukemia cells [180].

Anaplastic large cell lymphoma is an aggressive nonHodgkin's lymphoma, which is characterized by the occurrence of a fusion between nucleophosmin and the tyrosine kinase ALK. In a mouse model of this disease, the AP-1 members Jun and JunB were found to promote the expression of PDGF-B in the lymphoma cells [181]. The importance of the autocrine PDGF stimulation for tumorigenesis is illustrated by the finding that treatment of the transgenic mice with imatinib significantly prolonged their life. Moreover, treatment of a patient with anaplastic large cell lymphoma with imatinib resulted in rapid, complete and sustained remission [181].

\section{Prostate cancer}

Immunohistochemical stainings have revealed that PDGFR $\beta$ is upregulated in most primary and metastatic prostate cancer cells [182]. Moreover, PDGFR $\beta$ mRNA expression was identified by microarray analyses as one of five mRNAs that predict prostate cancer recurrence, the other four being chromogranin A, HOXC6, IPTR3 and sialyltransferase-1 [183]. Whereas the PDGFR $\beta$ ligand PDGF-B has not been found to be overexpressed in prostate tumors, the other PDGFR $\beta$ ligand, PDGF-D, is often expressed at high levels and its expression correlates to the degree of malignancy [7]. Overexpression of PDGF-D in a mouse model significantly enhanced prostate carcinoma onset and invasiveness [184]. Loss of PTEN, which enhances PI3-kinase signaling, promotes production of PDGF-D, whereas the AMP-activated kinase (AMPK) regulates PDGF-B expression [185]. Overexpression of PDGF$\mathrm{D}$ in PC3 prostate cancer cells was found to promote EMT and a stem cell phenotype, which may explain the increased invasiveness [186]. When PDGF-B and PDGF-D were transfected into non-malignant prostate epithelial cells, PDGF-D was found to induce cell migration and invasion more efficiently than PDGF-B [187]. The stronger effect of PDGF-D was dependent of the Jun MAP-kinase and involved shedding and activation of the serine protease matriptase. The mechanism behind the stronger tumorigenic effect of PDGF-D, compared to PDGF-B that binds to the same receptor, remains to be elucidated.

Interestingly, PDGF-D, but not PDGF-B, was able to induce osteoclast differentiation, and to upregulate the expression and nuclear translocation of nuclear factor of activated T cells 1 (NFAT-1), a master regulator of osteoclastogenesis [188]. This production of PDGF-D by prostate cancer cells is likely to be of importance for the establishment of bone metastases.

PDGFR $\alpha$ has also been implicated in prostate cancer. In a preclinical model of disseminated prostate cancer, it was shown that treatment with a neutralizing antibody against PDGFR $\alpha$ inhibited the growth of skeletal metastases [189,190]. Moreover, knock-down of PDGFR $\alpha$, as well as PDGFR $\beta$, by siRNA suppressed growth of prostate cancer cells in mice and suppressed tumor angiogenesis [191]. Interestingly, evidence have been presented that a soluble component of the bone marrow can activate PDGFR $\alpha$, and promote bone metastasis of prostate cancer cells, through a mechanism that does not require ligand-binding or receptor dimerization [192].

Preclinical studies have demonstrated potential benefit of inhibition of PDGFR $\beta$ signaling by imatinib in prostate cancer $[193,194]$. Whereas a Phase I clinical trial with imatinib combined with docetaxel showed some benefit [195], placebo-controlled clinical trials did not show any significantly increased progression free or overall survival [196,197]. Further clinical trials were halted because of excessive side effects; possibly, other PDGF receptor kinase inhibitors would be more useful. An interesting candidate is cediranib, which inhibits PDGF and VEGF receptor kinases and has been shown to inhibit intraosseous growth of PDGF-D positive prostate cancer cells in a mouse model [198].

\section{Liver cancer}

During the progression of hepatocellular carcinoma, and in conjunction with epithelial-mesenchymal transition (EMT), PDGF-A as well as PDGFR $\alpha$ and $\beta$ are induced [199]. Inhibition of PDGF receptor signaling was found to decrease cell migration in vitro and tumor growth in vivo, in a $\beta$-catenin-dependent manner, indicating an important role for PDGF signaling in hepatocyte tumor progression [200]. Sorafenib, which in addition to PDGFR inhibits Raf, VEGFR and Kit, is now standard treatment for patients with hepatocellular carcinoma. 
However, it is not clear how important PDGFR kinase inhibition is for the beneficial effects [201,202].

PDGF-A and PDGFR $\alpha$ mRNA and protein are often overexpressed in patients with cholangiocarcinoma; treatment of cholangiocarcinoma cell lines with the PDGF receptor kinase inhibitors imatinib or sunitinib suppressed cell viability and migration [203]. Sorafenib also inhibited cholangiocarcinoma cell growth and survival in vitro and in vivo [204]. In another study, myofibroblast-derived PDGF-BB was shown to provide survival signals for cholangiocarcinoma cells, thus protecting them from TRAIL-mediated cytotoxicity by enhancing Hedgehog signaling [205]. Targeting PDGFR $\alpha$ by imatinib sensitized cholangiocarcinoma cells to apoptotic stimuli in vitro and in vivo [206].

\section{Non-small cell lung cancer}

PDGF receptors are not expressed, or expressed at low levels, in normal lung epithelial cells, however, expression of PDGFR $\alpha$ has been reported in lung cancer cell lines and tumor tissue [207-209]. Expression of PDGFR $\beta$ was also seen, but mainly in the stromal cells. Increased expression of PDGFR $\beta$ was seen in the rare sarcomatoid type of non-small cell lung cancer [210]. Expression of PDGF and PDGF receptors in lung cancer was found to be associated with poor prognosis [211]. Inhibition of PDGF in preclinical models of non-small cell lung cancer by treatment with a neutralizing PDGFR $\alpha$ antibody (MEDI-575) caused a significant decrease in stromal fibroblast content but had only minor effect on tumor cell proliferation [212]. In addition, transfection of a non-receptor binding mutant of PDGF-A (PDGF-0) in A549 lung cancer cells, which inactivates the PDGF produced by these cells, led to a markedly decreased tumor growth in vivo because of impaired recruitment of periendothelial cells [213].

A Phase II clinical study explored the effect of imatinib combined with docetaxel for the treatment of recurrent non-small cell lung cancer, however, only one partial response and 4 stable disease out of 23 treated patients were seen [214]; thus, the study did not reach its objective. Another study focused on Asian patients who were treated with sunitinib; two partial responses and 7 stable disease were observed out of 18 patients treated [215]. Larger studies need to be conducted before it is possible to determine whether inhibition of PDGF receptors, with or without inhibition of VEGF receptors, is of any benefit for lung cancer patients.

\section{Breast cancer}

In breast cancer, expression of PDGF in tumor cells and PDGF receptors in stromal cells have been reported $[216,217]$. PDGF receptors are also expressed in the tumor cells, which correlate with tumor progression and invasion [70,218,219]. PDGF receptors have been observed to be upregulated upon IGF1 receptor independence in an animal model [220].

Combining imatinib treatment with radiotherapy showed a significantly stronger inhibition of cell proliferation compared to radiotherapy alone in a mouse model for breast cancer [221].

PDGF-D produced by cells in the stroma of breast cancers, e.g. adipose tissue-derived stem cells, was found to induce EMT of the cancer cells in a paracrine manner, thereby promoting the formation of cancer stem cells and tumorigenesis [222].

It remains to be determined whether inhibition of PDGF receptor signaling is of benefit for breast cancer patients. A possible subgroup that could benefit is patients with estrogen receptor positive tumors undergoing aromatase inhibition therapy, since this treatment has been found to be associated with an upregulation of PDGFR $\beta$ on the tumor cells [223].

\section{Colorectal cancer}

In colorectal cancers PDGF receptors are mainly expressed by stromal cells and pericytes [224,225], but PDGF receptor expression has also been noted on colorectal carcinoma cell lines [226,227]. Expression of PDGF receptors is associated with poor prognosis for patients with colorectal cancer [228]. Studies using preclinical models have shown that colorectal cancer cells can acquire PDGFR $\beta$ in conjunction with EMT, and that activation of this receptor promotes metastasis [229].

\section{Other tumors}

Several other tumor types have been reported to involve overactive PDGF signaling in the tumor cells. Thus, PDGF-D and PDGFR $\beta$ were found to be co-expressed in several mesothelioma cell lines, resulting in autocrine stimulation of cell proliferation [230].

In Wilms' tumor of the kidney, PDGF-A and PDGFR $\alpha$ was expressed in $50 \%$ and $55 \%$ of the cases, respectively, in a cohort of 62 patients; interestingly, expression of PDGF-A and PDGFR $\alpha$ correlated with good prognosis [231]. It is possible that expression of PDGF-A and PDGFR $\alpha$ reflect a differentiated phenotype and therefore correlates to favorable prognosis. This is in contrast to breast [232], ovarian [233] and lung [207,234] carcinomas, in which cases PDGF and PDGF receptor expression correlate to poor prognosis.

The childhood tumor neuroblastoma arises from the neural crest remnants of the sympathetic nervous system, and has been shown to express PDGF receptors [235], as well as c-Kit [236]. Whereas imatinib inhibited neuroblastoma cells in vitro and in xenografts, little or no treatment effect as single agent was seen in children with relapsed or refractory neuroblastoma [237]. 
Activation of the hedgehog pathway occurs frequently in basal cell carcinoma of the skin. The transcription factor Gli1, which is activated in the hedgehog pathway, activates the promoter of the PDGFR $\alpha$ gene and thus promotes PDGFR $\alpha$ expression; this is an important mechanism by which hedgehog signaling promotes tumorigenesis [238], and suggests that PDGF inhibition could be beneficial in skin tumor treatment.

Leydig cell tumors of the testis express high levels of PDGF isoforms and PDGF receptors [239]. However, treatment of a patient with imatinib was not successful [240]. On the other hand, human testicular germ tumors also express PDGF receptors, and treatment with sunitinib as single agent showed beneficial effects even in cisplatinresistant tumors in a mouse model [241].

Overexpression of PDGF-A, $-\mathrm{B}$ and $-\mathrm{C}$ isoforms and both PDGF receptors were found to be crucial for the development of thyroid nodules and recurrent goitre [242].

\section{Targeting PDGF in tumor stroma}

In addition to tumor cells, non-tumor cells in solid tumors, such as macrophages and endothelial cells, produce PDGF isoforms. PDGF receptors are expressed on pericytes and smooth muscle cells of vessels, as well as on fibroblasts and myofibroblasts. Recent studies have shown that targeting of cells in tumor stroma can be beneficial in tumor treatment, particularly if combined with targeting of the tumor cells directly.

\section{Anti-angiogenic treatment}

Angiogenesis is promoted by several different factors, including VEGF, FGF, TGF $\beta$, angiopoietins and PDGF [243]. A monoclonal antibody against VEGF, bevacizumab, is already used clinically. PDGF has an accessory role in angiogenesis and, in particular, promotes pericyte recruitment to vessels. Studies using different mouse models have shown that anti-angiogenic therapy can be more efficient by combination of inhibition of VEGF signaling, targeting endothelial cells, and PDGF signaling, targeting pericytes [243-248]. Combination therapy probably interrupts the trophic relationship between endothelial cells and pericytes. Simultaneous inhibition of fibroblast growth factor (FGF) may be even more beneficial $[50,249]$. Interestingly, resistance to anti-VEGF treatment has been shown to involve increased expression of PDGF-C [250]. However, the effect of anti-PDGF treatment may be context-dependent. Thus, no synergistic effect was seen by the combination of anti-VEGF and anti-PDGF treatment in mouse models of colorectal and pancreatic cancer; in fact PDGF overexpression was found to inhibit endothelial cells and angiogenesis by intensive pericyte recruitment [251]. Another complication was reported from a clinical study in which CDP860, an engineered Fab' fragment inhibiting PDGFR $\beta$, was used; the study had to be interrupted since seven of eight patients developed fluid retention and three significant ascites upon treatment [47].

Bone-marrow-derived mesenchymal stem cells have been shown to exert an anti-angiogenic effect in preclinical models of glioma by inhibiting the recruitment of endothelial progenitor cells through decreased expression of PDGF-BB and other angiogenic factors [252].

A mechanism whereby PDGF-BB promotes tumor angiogenesis and tumor growth was recently presented; by induction of erythropoietin, PDGF-BB promotes endothelial cell proliferation, migration, sprouting and tube formation, and promotes extramodullary hematopoiesis leading to increased oxygen perfusion and protection against tumor-associated anemia [253]. Another mechanism was unraveled by studies of chronic lymphocytic leukemia; PDGF secreted by these tumor cells stimulated mesenchymal stromal cells to produce VEGF [254].

PDGF-BB has also been shown to stimulate lymphangiogenesis [255], and to promote lymphatic metastasis in gastric carcinoma [256]. In papillary thyroid cancer, expression of PDGFR $\alpha$ correlated with lymphatic metastases [257].

\section{Cancer-associated fibroblasts}

It has become increasingly appreciated that stromal cells of solid tumors contribute to tumorigenesis [258,259]. Such cells include, in addition to vascular cells, e.g. macrophages and cancer-associated fibroblasts (CAFs). The latter cell type is heterogeneous and may derive from tissue fibroblasts, bone-marrow-derived progenitor cells or transdifferentiating epithelial cells. The various cell types of the stromal compartment contribute to tumorigenesis by secreting various growth factors and cytokines which promotes growth, survival and migration of the tumor cells, as well as epithelial-mesenchymal transition and tumor angiogenesis.

PDGF receptors are expressed on CAFs and there are several reports that PDGF stimulation affects CAF function. Thus, ectopic expression of PDGF-BB was found to promote stroma formation and tumor growth of melanoma [260], tumorigenesis of immortalized keratinocytes [261] and growth of prostate cancer [262]. Tumor cellderived PDGF-AA was found to recruit CAFs in xenograft studies of breast [263] and lung [264] carcinomas. Transgenic expression of PDGF-CC in mouse liver cells resulted in tissue fibrosis and promoted development of hepatocellular carcinoma [265]. Moreover, expression of PDGF-CC in mouse models promoted recruitment of CAFs and growth of malignant melanoma [266] and liver metastasis of colorectal cancer [267]. Finally, ectopic expression of PDGF-DD was found to promote tumorigenesis and angiogenesis [268,269]. Stromal PDGF receptor expression has been shown to be associated with poor prognosis in 
breast and prostate cancer [270,271], in colorectal cancer [228,272] and in pancreatic carcinoma [273].

CAFs and myofibroblasts make contacts with collagen fibers of the extracellular matrix. PDGF stimulation of these cells causes cell contraction leading to an increased tumor interstitial pressure [71]. This is an obstacle in treatment of tumor patients with chemotherapy, since it decreases transcapillary transport and drug uptake. Treatment of mice with different types of solid tumors with PDGF antagonists was found to decrease IFP, to increase drug uptake, and to improve the efficiency of treatment with chemotherapeutic drugs [274-276]. In addition, treatment with VEGF antagonists was also found to decrease tumor IFP [277,278], and the combination of PDGF and VEGF antagonists gave an additive effect [279].

Targeting PDGF receptors in the stroma has been found to inhibit lung cancer growth $[280,281]$ and bone metastasis [282], and colon cancer growth and metastasis [283] in mouse models.

\section{Future perspectives}

The fact that PDGF and/or PDGF receptors are overexpressed or mutated in different tumors makes it desirable to investigate whether PDGF or PDGF receptor antagonists can be used to treat patients with these diseases. Some encouraging results have already been obtained by treatment of some rather rare tumors driven by overactive PDGF receptor signaling due to mutations of either PDGF or PDGF receptor genes. However, resistance mechanisms limit the success of such treatments, and anti-PDGF receptor treatment most likely will have to be combined with other signal transduction inhibitors, chemotherapeutical agents or other treatments, in order to achieve long lasting remissions.

In solid tumors PDGF receptors are expressed on pericytes of vessels and on fibroblasts and myofibroblasts of the stroma. Tumor cells are dependent on their environment for their proliferation and survival, making nonmalignant PDGF receptor expressing cells interesting targets in tumor treatment. Further studies are needed in order to explore whether anti-PDGF receptor treatment targeting non-malignant cells in the tumor, in combination with anti-tumor cell treatment, will be of benefit for patients. It also remains to be determined whether selective inhibition of PDGF or PDGF receptors by e.g. monoclonal antibodies or ligand traps, or more unspecific inhibition of PDGF receptor kinases by low molecular weight inhibitors, will give the best clinical results.

\section{Competing interest}

The author declare that he has no competing interests.

\section{Acknowledgements}

Ingegärd Schiller is thanked for her valuable help in the preparation of this article.
Received: 8 November 2013 Accepted: 11 December 2013

Published: 20 December 2013

\section{References}

1. Heldin C-H, Westermark B: Mechanism of action and in vivo role of platelet-derived growth factor. Physiol Rev 1999, 79:1283-1316.

2. Andrae J, Gallini R, Betsholtz C: Role of platelet-derived growth factors in physiology and medicine. Genes Dev 2008, 22:1276-1312.

3. Heldin C-H: Targeting the PDGF signaling pathway in the treatment of non-malignant diseases. J Neuroimmune Pharmacol 2013. in press.

4. Fredriksson L, Li H, Fieber C, Li X, Eriksson U: Tissue plasminogen activator is a potent activator of PDGF-CC. EMBO J 2004, 23:3793-3802.

5. Fredriksson L, Li H, Eriksson U: The PDGF family: four gene products form five dimeric isoforms. Cytokine Growth Factor Rev 2004, 15:197-204.

6. Ustach CV, Kim HR: Platelet-derived growth factor $D$ is activated by urokinase plasminogen activator in prostate carcinoma cells. Mol Cell Biol 2005, 25:6279-6288.

7. Ustach CV, Huang W, Conley-LaComb MK, Lin CY, Che M, Abrams J, Kim HR: A novel signaling axis of matriptase/PDGF-D/ $\beta$-PDGFR in human prostate cancer. Cancer Res 2010, 70:9631-9640.

8. Omura T, Heldin C-H, Östman A: Immunoglobulin-like domain 4-mediated receptor-receptor interactions contribute to platelet-derived growth factor-induced receptor dimerization. J Biol Chem 1997, 272:12676-12682.

9. Yang Y, Yuzawa S, Schlessinger J: Contacts between membrane proximal regions of the PDGF receptor ectodomain are required for receptor activation but not for receptor dimerization. Proc Natl Acad Sci USA 2008, 105:7681-7686.

10. Baxter RM, Secrist JP, Vaillancourt RR, Kazlauskas A: Full activation of the platelet-derived growth factor beta-receptor kinase involves multiple events. J Biol Chem 1998, 273:17050-17055.

11. Irusta PM, Luo Y, Bakht O, Lai CC, Smith SO, DiMaio D: Definition of an inhibitory juxtamembrane WW-like domain in the platelet-derived growth factor beta receptor. J Biol Chem 2002, 277:38627-38634

12. Chiara F, Bishayee S, Heldin C-H, Demoulin J-B: Autoinhibition of the platelet-derived growth factor $\beta$ receptor tyrosine kinase by its Cterminal tail. J Biol Chem 2004, 279:19732-19738.

13. Heldin C-H, Östman A, Rönnstrand L: Signal transduction via platelet-derived growth factor receptors. Biochim Biophys Acta 1998, 1378:F79-F113.

14. Bae YS, Sung J-Y, Kim O-S, Kim YJ, Hur KC, Kazlauskas A, Rhee SG: Plateletderived growth factor-induced $\mathrm{H}_{2} \mathrm{O}_{2}$ production requires the activation of phosphatidylinositol 3-kinase. J Biol Chem 2000, 275:10527-10531.

15. Sundaresan M, Yu ZX, Ferrans VJ, Irani K, Finkel T: Requirement for generation of $\mathrm{H}_{2} \mathrm{O}_{2}$ for platelet-derived growth factor signal transduction. Science 1995, 270:296-299.

16. Jurek A, Amagasaki K, Gembarska A, Heldin C-H, Lennartsson J: Negative and positive regulation of MAPK phosphatase 3 controls platelet-derived growth factor-induced Erk activation. J Biol Chem 2009, 284:4626-4634.

17. Fantl WJ, Escobedo JA, Martin GA, Turck CW, del Rosario M, McCormick F, Williams LT: Distinct phosphotyrosines on a growth factor receptor bind to specific molecules that mediate different signaling pathways. Cell 1992, 69:413-423.

18. Jurek A, Heldin C-H, Lennartsson J: Platelet-derived growth factor-induced signaling pathways interconnect to regulate the temporal pattern of Erk1/2 phosphorylation. Cell Signal 2011, 23:280-287.

19. Haj FG, Markova B, Klaman LD, Bohmer FD, Neel BG: Regulation of receptor tyrosine kinase signaling by protein tyrosine phosphatase-1B. J Biol Chem 2003, 278:739-744

20. Persson C, Sävenhed C, Bourdeau A, Tremblay ML, Markova B, Böhmer FD, Haj FG, Neel BG, Elson A, Heldin C-H, et al: Site-selective regulation of platelet-derived growth factor $\beta$ receptor tyrosine phosphorylation by Tcell protein tyrosine phosphatase. Mol Cell Biol 2004, 24:2190-2201.

21. Kovalenko M, Denner K, Sandström J, Persson C, Groß S, Jandt E, Vilella R, Böhmer F, Östman A: Site-selective dephosphorylation of the plateletderived growth factor $\beta$-receptor by the receptor-like protein-tyrosine phosphatase DEP-1.J Biol Chem 2000, 275:16219-16226.

22. Kappert K, Paulsson J, Sparwel J, Leppänen O, Hellberg C, Östman A, Micke $P$ : Dynamic changes in the expression of DEP-1 and other PDGF receptor-antagonizing PTPs during onset and termination of neointima formation. FASEB J 2007, 21:523-534.

23. Peng Z-Y, Cartwright CA: Regulation of the Src tyrosine kinase and Syp tyrosine phosphatase by their cellular association. Oncogene 1995 11:1955-1962. 
24. Dance M, Montagner A, Salles JP, Yart A, Raynal P: The molecular functions of Shp2 in the Ras/Mitogen-activated protein kinase (ERK1/2) pathway. Cell Signal 2008, 20:453-459.

25. Saito Y, Haendeler J, Hojo Y, Yamamoto K, Berk BC: Receptor heterodimerization: essential mechanism for platelet-derived growth factor-induced epidermal growth factor receptor transactivation. Mol Cell Biol 2001, 21:6387-6394.

26. Sundberg $C$, Rubin $K$ : Stimulation of $\beta_{1}$ integrins on fibroblasts induces PDGF independent tyrosine phosphorylation of PDGF $\beta$-receptors. J Cell Biol 1996, 132:741-752.

27. Loukinova E, Ranganathan S, Kuznetsov S, Gorlatova N, Migliorini MM, Loukinov D, Ulery PG, Mikhailenko I, Lawrence DA, Strickland DK: Plateletderived growth factor (PDGF)-induced tyrosine phosphorylation of the low density lipoprotein receptor-related protein (LRP). Evidence for integrated co-receptor function between LRP and the PDGF. J Biol Chem 2002, 277:15499-15506.

28. Boucher P, Liu P, Gotthardt M, Hiesberger T, Anderson RG, Herz J: Plateletderived growth factor mediates tyrosine phosphorylation of the cytoplasmic domain of the low density lipoprotein receptor-related protein in caveolae. J Biol Chem 2002, 277:15507-15513.

29. Newton CS, Loukinova E, Mikhailenko I, Ranganathan S, Gao Y, Haudenschild C, Strickland DK: Platelet-derived growth factor receptor- $\beta$ (PDGFR- $\beta$ ) activation promotes its association with the low density lipoprotein receptor-related protein (LRP). Evidence for co-receptor function. J Biol Chem 2005, 280:27872-27878.

30. Li L, Heldin C-H, Heldin P: Inhibition of platelet-derived growth factor-BBinduced receptor activation and fibroblast migration by hyaluronan activation of CD44. J Biol Chem 2006, 281:26512-26519.

31. Miyake S, Mullane-Robinson KP, Lill NL, Douillard P, Band H: Cbl-mediated negative regulation of platelet-derived growth factor receptordependent cell proliferation - a critical role for Cbl tyrosine kinasebinding domain. J Biol Chem 1999, 274:16619-16628.

32. Wang Y, Pennock SD, Chen X, Kazlauskas A, Wang Z: Platelet-derived growth factor receptor-mediated signal transduction from endosomes. $J$ Biol Chem 2004, 279:8038-8046

33. Hellberg C, Schmees C, Karlsson S, Åhgren A, Heldin C-H: Activation of protein kinase $C a$ is necessary for sorting the PDGF $\beta$-receptor to Rab4adependent recycling. Mol Biol Cell 2009, 20:2856-2863.

34. Schmees C, Villaseñor R, Zheng W, Ma H, Zerial M, Heldin C-H, Hellberg C: Macropinocytosis of the PDGF $\beta$-receptor promotes fibroblast transformation by H-RasG12V. Mol Biol Cell 2012, 23:2571-2582.

35. Soriano P: The PDGFa receptor is required for neural crest cell development and for normal patterning of the somites. Development 1997, 124:2691-2700

36. Boström $H$, Willetts $K$, Pekny M, Levéen $P$, Lindahl $P$, Hedstrand H, Pekna M, Hellström M, Gebre-Medhin S, Schalling M, et al: PDGF-A signaling is a critical event in lung alveolar myofibroblast development and alveogenesis. Cell 1996, 85:863-873.

37. Karlsson L, Lindahl P, Heath JK, Betsholtz C: Abnormal gastrointestinal development in PDGF-A and PDGFR- $a$ deficient mice implicates a novel mesenchymal structure with putative instructive properties in villus morphogenesis. Development 2000, 127:3457-3466.

38. Soriano P: Abnormal kidney development and hematological disorders in PDGF $\beta$-receptor mutant mice. Genes Dev 1994, 8:1888-1896.

39. Levéen P, Pekny M, Gebre-Medhin S, Swolin B, Larsson E, Betsholtz C: Mice deficient for PDGF B show renal, cardiovascular, and hematological abnormalities. Genes Dev 1994, 8:1875-1887.

40. Lindahl P, Johansson BR, Levéen P, Betsholtz C: Pericyte loss and microaneurysm formation in PDGF-B-deficient mice. Science 1997, 277:242-245.

41. Lindahl P, Karlsson L, Hellström M, Gebre-Medhin S, Willetts K, Heath JK, Betsholtz C: Alveogenesis failure in PDGF-A-deficient mice is coupled to lack of distal spreading of alveolar smooth muscle cell progenitors during lung development. Development 1997, 124:3943-3953.

42. Ohashi S, Natsuizaka M, Naganuma S, Kagawa S, Kimura S, Itoh H, Kalman RA, Nakagawa M, Darling DS, Basu D, et al: A NOTCH3-mediated squamous cell differentiation program limits expansion of EMT-competent cells that express the ZEB transcription factors. Cancer Res 2011, 71:6836-6847.

43. Robson MC, Phillips LG, Thomason A, Robson LE, Pierce GF: Plateletderived growth factor BB for the treatment of chronic pressure ulcers. Lancet 1992, 339:23-25.
44. Rodt SÅ, Åhlén K, Berg A, Rubin K, Reed RK: A novel physiological function for platelet-derived growth factor-BB in rat dermis. J Physiol 1996, 495:193-200.

45. Green LS, Jellinek D, Jenison R, Östman A, Heldin C-H, Janjic N: Inhibitory DNA ligands to platelet-derived growth factor B-chain. Biochem 1996, 35:14413-14424.

46. Hawthorne T, Giot L, Blake L, Kuang B, Gerwien R, Smithson G, Hahne W, Mansfield T, Starling GC, Pochart P, et al: A phase I study of CR002, a fullyhuman monoclonal antibody against platelet-derived growth factor-D. Int J Clin Pharmacol Ther 2008, 46:236-244.

47. Jayson GC, Parker GJ, Mullamitha S, Valle JW, Saunders M, Broughton L, Lawrance J, Carrington B, Roberts C, Issa B, et al: Blockade of plateletderived growth factor receptor-beta by CDP860, a humanized, PEGylated di-Fab', leads to fluid accumulation and is associated with increased tumor vascularized volume. J Clin Oncol 2005, 23:973-981.

48. Shen J, Vil MD, Zhang H, Tonra JR, Rong LL, Damoci C, Prewett M, Deevi DS, Kearney J, Surguladze D, et al: An antibody directed against PDGF receptor $\beta$ enhances the antitumor and the anti-angiogenic activities of an anti-VEGF receptor 2 antibody. Biochem Biophys Res Commun 2007, 357:1142-1147.

49. Shen J, Vil MD, Prewett M, Damoci C, Zhang H, Li H, Jimenez X, Deevi DS, lacolina $M$, Kayas $A$, et al: Development of a fully human anti-PDGFR $\beta$ antibody that suppresses growth of human tumor xenografts and enhances antitumor activity of an anti-VEGFR2 antibody. Neoplasia 2009, 11:594-604

50. Socinski MA: Multitargeted receptor tyrosine kinase inhibition: an antiangiogenic strategy in non-small cell lung cancer. Cancer Treat Rev 2011, 37:611-617

51. Chao Q, Sprankle KG, Grotzfeld RM, Lai AG, Carter TA, Velasco AM, Gunawardane RN, Cramer MD, Gardner MF, James J, et al: Identification of $N$-(5-tert-butyl-isoxazol-3-yl)- $N^{\prime}$-\{4-[7-(2-morpholin-4-yl-ethoxy) imidazo $[2,1-b][1,3]$ benzothiazol-2-yl] phenyl\} urea dihydrochloride (AC220), a uniquely potent, selective, and efficacious FMS-like tyrosine kinase-3 (FLT3) inhibitor. J Med Chem 2009, 52:7808-7816.

52. Kampa-Schittenhelm KM, Heinrich MC, Akmut F, Dohner H, Dohner K, Schittenhelm MM: Quizartinib (AC220) is a potent second generation class III tyrosine kinase inhibitor that displays a distinct inhibition profile against mutant-FLT3, -PDGFRA and -KIT isoforms. Mol Cancer 2013, 12:19.

53. Huang WS, Metcalf CA, Sundaramoorthi R, Wang Y, Zou D, Thomas RM, Zhu X, Cai L, Wen D, Liu S, et al: Discovery of 3-[2-(imidazo [1,2-b] \pyridazin-3yl) ethynyl]-4-methyl- $N$-\{4-[(4-methylpiperazin-1-yl) methyl]-3(trifluoromethyl) phenyl\} benzamide (AP24534), a potent, orally active pan-inhibitor of breakpoint cluster region-abelson (BCR-ABL) kinase including the T315I gatekeeper mutant. J Med Chem 2010, 53:4701-4719.

54. De Falco V, Buonocore P, Muthu M, Torregrossa L, Basolo F, Billaud M, Gozgit JM, Carlomagno F, Santoro M: Ponatinib (AP24534) is a novel potent inhibitor of oncogenic RET mutants associated with thyroid cancer. J Clin Endocrinol Metab 2013, 98:E811-E819.

55. Pietras K, Sjöblom T, Rubin K, Heldin C-H, Östman A: PDGF receptors as cancer drug targets. Cancer Cell 2003, 3:439-443.

56. O'Brien KP, Seroussi E, Dal Cin P, Sciot R, Mandahl N, Fletcher JA, Turc-Care C, Dumanski JP: Various regions within the a-helical domain of the COL1A1 gene are fused to the second exon of the PDGFB gene in dermatofibrosarcomas and giant-cell fibroblastomas. Gene Chrom Cancer 1998, 23:187-193.

57. Simon M-P, Pedeutour F, Sirvent N, Grosgeorge J, Minoletti F, Coindre J-M Terrier-Lacombe M-J, Mandahl N, Craver RD, Blin N, et al: Deregulation of the platelet-derived growth factor B-chain gene via fusion with collagen gene COL1A1 in dermatofibrosarcoma protuberans and giant-cell fibroblastoma. Nature Genet 1997, 15:95-98.

58. Shimizu A, O'Brien KP, Sjöblom T, Pietras K, Buchdunger E, Collins VP, Heldin C-H, Dumanski JP, Östman A: The dermatofibrosarcoma protuberansassociated collagen type la1/platelet-derived growth factor (PDGF) Bchain fusion gene generates a transforming protein that is processed to functional PDGF-BB. Cancer Res 1999, 59:3719-3723.

59. Heinrich MC, Corless CL, Duensing A, McGreevey L, Chen CJ, Joseph N, Singer S, Griffith DJ, Haley A, Town A, et al: PDGFRA activating mutations in gastrointestinal stromal tumors. Science 2003, 299:708-710.

60. Toffalini F, Demoulin JB: New insights into the mechanisms of hematopoietic cell transformation by activated receptor tyrosine kinases. Blood 2010, 116:2429-2437. 
61. Fleming TP, Saxena A, Clark WC, Robertson JT, Oldfield EH, Aaronson SA, Ali IU: Amplification and/or overexpression of platelet-derived growth factor receptors and epidermal growth factor receptor in human glial tumors. Cancer Res 1992, 52:4550-4553.

62. Kumabe T, Sohma Y, Kayama T, Yoshimoto T, Yamamoto T: Amplification of a-platelet-derived growth factor receptor gene lacking an exon coding for a portion of the extracellular region in a primary brain tumor of glial origin. Oncogene 1992, 7:627-633.

63. Puputti M, Tynninen $O$, Sihto H, Blom T, Maenpaa H, Isola J, Paetau A, Joensuu $H$, Nupponen NN: Amplification of KIT, PDGFRA, VEGFR2, and EGFR in gliomas. Mol Cancer Res 2006, 4:927-934.

64. Smith JS, Wang XY, Qian J, Hosek SM, Scheithauer BW, Jenkins RB, James $C D$ : Amplification of the platelet-derived growth factor receptor-A (PDGFRA) gene occurs in oligodendrogliomas with grade IV anaplastic features. J Neuropathol Exp Neurol 2000, 59:495-503.

65. Arai H, Ueno T, Tangoku A, Yoshino S, Abe T, Kawauchi S, Oga A, Furuya T, Oka M, Sasaki K: Detection of amplified oncogenes by genome DNA microarrays in human primary esophageal squamous cell carcinoma: comparison with conventional comparative genomic hybridization analysis. Cancer Genet Cytogenet 2003, 146:16-21.

66. Zhao J, Roth J, Bode-Lesniewska B, Pfaltz M, Heitz PU, Komminoth P: Combined comparative genomic hybridization and genomic microarray for detection of gene amplifications in pulmonary artery intimal sarcomas and adrenocortical tumors. Genes Chromosomes Cancer 2002, 34:48-57.

67. Dewaele B, Floris G, Finalet-Ferreiro J, Fletcher CD, Coindre JM, Guillou L Hogendoorn PC, Wozniak A, Vanspauwen V, Schoffski P, et al: Coactivated platelet-derived growth factor receptor a and epidermal growth factor receptor are potential therapeutic targets in intimal sarcoma. Cancer Res 2010, 70:7304-7314.

68. Clarke ID, Dirks PB: A human brain tumor-derived PDGFR-a deletion mutant is transforming. Oncogene 2003, 22:722-733.

69. Thiery JP, Acloque H, Huang RY, Nieto MA: Epithelial-mesenchymal transitions in development and disease. Cell 2009, 139:871-890.

70. Jechlinger M, Sommer A, Moriggl R, Seither P, Kraut N, Capodiecci P, Donovan M, Cordon-Cardo C, Beug H, Grunert S: Autocrine PDGFR signaling promotes mammary cancer metastasis. J Clin Invest 2006, 116:15611570 .

71. Heldin C-H, Rubin K, Pietras K, Östman A: High interstitial fluid pressure an obstacle in cancer therapy. Nat Rev Cancer 2004, 4:806-813.

72. Weinstein IB, Joe A: Oncogene addiction. Cancer Res 2008, 68:3077-3080.

73. Deinhardt F: The biology of primate retrovirus. In Viral oncology. Edited by Klein G. New York: Raven Press; 1980:359-398.

74. Waterfield MD, Scrace GT, Whittle N, Stroobant P, Johnsson A, Wasteson $\AA$, Westermark B, Heldin C-H, Huang JS, Deuel TF: Platelet-derived growth factor is structurally related to the putative transforming protein $\mathrm{p} 28^{\text {sis }}$ of simian sarcoma virus. Nature (London) 1983, 304:35-39.

75. Doolittle RF, Hunkapiller MW, Hood LE, Devare SD, Robbins KC, Aaronson SA, Antoniades HN: Simian sarcoma virus onc gene, $\mathrm{v}$-sis, is derived from the gene (or genes) encoding a platelet-derived growth factor. Science 1983, 221:275-277.

76. Nistér M, Libermann TA, Betsholtz C, Pettersson M, Claesson-Welsh L, Heldin $\mathrm{C}-\mathrm{H}$, Schlessinger J, Westermark B: Expression of messenger RNAs for platelet-derived growth factor and transforming growth factor- $a$ and their receptors in human malignant glioma cell lines. Cancer Res 1988, 48:3910-3918.

77. Lokker NA, Sullivan CM, Hollenbach SJ, Israel MA, Giese NA: Platelet-derived growth factor (PDGF) autocrine signaling regulates survival and mitogenic pathways in glioblastoma cells: evidence that the novel PDGF-C and PDGF-D ligands may play a role in the development of brain tumors. Cancer Res 2002, 62:3729-3735.

78. Hermanson M, Funa K, Hartman M, Claesson-Welsh L, Heldin C-H, Westermark B, Nistér M: Platelet-derived growth factor and its receptors in human glioma tissue: expression of messenger RNA and protein suggests the presence of autocrine and paracrine loops. Cancer Res 1992, 52:3213-3219.

79. Di Rocco F, Carroll RS, Zhang JP, Black PM: Platelet-derived growth factor and its receptor expression in human oligodendrogliomas. Neurosurgery 1998, 42:341-346.

80. Martinho O, Longatto-Filho A, Lambros MB, Martins A, Pinheiro C, Silva A Pardal F, Amorim J, Mackay A, Milanezi F, et al: Expression, mutation and copy number analysis of platelet-derived growth factor receptor $A$ (PDGFRA) and its ligand PDGFA in gliomas. Br J Cancer 2009, 101:973-982.
81. Hermanson M, Funa K, Koopmann J, Maintz D, Waha A, Westermark B, Heldin C-H, Wiestler OD, Louis DN, von Deimling A, Nistér M: Association of loss of heterozygosity on chromosome $17 \mathrm{p}$ with high platelet-derived growth factor a receptor expression in human malignant gliomas. Cancer Res 1996, 56:164-171.

82. Guha A, Dashner K, Black PM, Wagner JA, Stiles CD: Expression of PDGF and PDGF receptors in human astrocytoma operation specimens supports the existence of an autocrine loop. Int J Cancer 1995, 60:168-173.

83. Maxwell M, Naber SP, Wolfe HJ, Galanopoulos T, Hedley-Whyte ET, Black PM, Antoniades HN: Coexpression of platelet-derived growth factor (PDGF) and PDGF-receptor genes by primary human astrocytomas may contribute to their development and maintenance. J Clin Invest 1990, 86:131-140.

84. Plate $\mathrm{KH}$, Breier $\mathrm{G}$, Farrell $\mathrm{CL}$, Risau W: Platelet-derived growth factor receptor- $\beta$ is induced during tumor development and upregulated during tumor progression in endothelial cells in human gliomas. Lab Invest 1992, 67:529-534.

85. Rand V, Huang J, Stockwell T, Ferriera S, Buzko O, Levy S, Busam D, Li K, Edwards JB, Eberhart $C$, et al: Sequence survey of receptor tyrosine kinases reveals mutations in glioblastomas. Proc Natl Acad Sci U S A 2005, 102:14344-14349.

86. Kumabe T, Sohma Y, Kayama T, Yoshimoto T, Yamamoto T: Overexpression and amplification of alpha-PDGF receptor gene lacking exons coding for a portion of the extracellular region in a malignant glioma. Tohoku J Exp Med 1992, 168:265-269.

87. Verhaak RG, Hoadley KA, Purdom E, Wang V, Qi Y, Wilkerson MD, Miller CR, Ding L, Golub T, Mesirov JP, et al: Integrated genomic analysis identifies clinically relevant subtypes of glioblastoma characterized by abnormalities in PDGFRA, IDH1, EGFR, and NF1. Cancer Cell 2010, 17:98-110.

88. Paugh BS, Zhu X, Qu C, Endersby R, Diaz AK, Zhang J, Bax DA, Carvalho D, Reis RM, Onar-Thomas A, et al: Novel oncogenic PDGFRA mutations in pediatric high-grade gliomas. Cancer Res 2013, 73:6219-6229.

89. Ozawa T, Brennan CW, Wang L, Squatrito M, Sasayama T, Nakada M, Huse JT, Pedraza A, Utsuki S, Yasui Y, et al: PDGFRA gene rearrangements are frequent genetic events in PDGFRA-amplified glioblastomas. Genes Dev 2010, 24:2205-2218.

90. Uhrbom L, Hesselager G, Nistér M, Westermark B: Induction of brain tumors in mice using a recombinant platelet-derived growth factor Bchain retrovirus. Cancer Res 1998, 58:5275-5279.

91. Uhrbom L, Hesselager G, Östman A, Nistér M, Westermark B: Dependence of autocrine growth factor stimulation in platelet-derived growth factorB-induced mouse brain tumor cells. Int J Cancer 2000, 85:398-406.

92. Hesselager G, Uhrbom L, Westermark B, Nister M: Complementary effects of platelet-derived growth factor autocrine stimulation and p53 or Ink4a-Arf deletion in a mouse glioma model. Cancer Res 2003, 63:4305-4309.

93. See WL, Miller JP, Squatrito M, Holland E, Resh MD, Koff A: Defective DNA double-strand break repair underlies enhanced tumorigenesis and chromosomal instability in p27-deficient mice with growth factorinduced oligodendrogliomas. Oncogene 2010, 29:1720-1731.

94. Tchougounova E, Kastemar M, Brasater D, Holland EC, Westermark B, Uhrbom L: Loss of Arf causes tumor progression of PDGFB-induced oligodendroglioma. Oncogene 2007, 26:6289-6296.

95. Liu KW, Feng H, Bachoo R, Kazlauskas A, Smith EM, Symes K, Hamilton RL, Nagane M, Nishikawa R, Hu B, Cheng SY: SHP-2/PTPN11 mediates gliomagenesis driven by PDGFRA and INK4A/ARF aberrations in mice and humans. J Clin Invest 2011, 121:905-917.

96. Appolloni I, Calzolari F, Tutucci E, Caviglia S, Terrile M, Corte G, Malatesta P: PDGF-B induces a homogeneous class of oligodendrogliomas from embryonic neural progenitors. Int J Cancer 2009, 124:2251-2259.

97. Calzolari F, Appolloni I, Tutucci E, Caviglia S, Terrile M, Corte G, Malatesta P: Tumor progression and oncogene addiction in a PDGF-B-induced model of gliomagenesis. Neoplasia 2008, 10:1373-1382. following 1382.

98. Dai C, Celestino JC, Okada Y, Louis DN, Fuller GN, Holland EC: PDGF autocrine stimulation dedifferentiates cultured astrocytes and induces oligodendrogliomas and oligoastrocytomas from neural progenitors and astrocytes in vivo. Genes Dev 2001, 15:1913-1925.

99. Assanah M, Lochhead R, Ogden A, Bruce J, Goldman J, Canoll P: Glial progenitors in adult white matter are driven to form malignant gliomas 
by platelet-derived growth factor-expressing retroviruses. J Neurosci 2006, 26:6781-6790.

100. Nazarenko I, Hedren A, Sjodin H, Orrego A, Andrae J, Afink GB, Nister M, Lindstrom MS: Brain abnormalities and glioma-like lesions in mice overexpressing the long isoform of PDGF-A in astrocytic cells. PLOS One 2011, 6:e18303.

101. Kim Y, Kim E, Wu Q, Guryanova O, Hitomi M, Lathia JD, Serwanski D, Sloan $A E$, Weil RJ, Lee J, et al: Platelet-derived growth factor receptors differentially inform intertumoral and intratumoral heterogeneity. Genes Dev 2012, 26:1247-1262

102. Jiang $Y$, Boije $M$, Westermark $B$, Uhrbom L: PDGF-B can sustain selfrenewal and tumorigenicity of experimental glioma-derived cancerinitiating cells by preventing oligodendrocyte differentiation. Neoplasia 2011, 13:492-503.

103. Holdhoff M, Kreuzer KA, Appelt C, Scholz R, Na IK, Hildebrandt B, Riess $H$, Jordan A, Schmidt CA, Van Etten RA, et al: Imatinib mesylate radiosensitizes human glioblastoma cells through inhibition of plateletderived growth factor receptor. Blood Cells Mol Dis 2005, 34:181-185.

104. Wen PY, Yung WK, Lamborn KR, Dahia PL, Wang Y, Peng B, Abrey LE, Raizer J, Cloughesy TF, Fink K, et al: Phase I/II study of imatinib mesylate for recurrent malignant gliomas: North American brain tumor consortium study 99-08. Clin Cancer Res 2006, 12:4899-4907.

105. Raymond E, Brandes AA, Dittrich C, Fumoleau P, Coudert B, Clement PM, Frenay M, Rampling R, Stupp R, Kros JM, et al: Phase II study of imatinib in patients with recurrent gliomas of various histologies: a European organisation for research and treatment of cancer brain tumor group study. J Clin Oncol 2008, 26:4659-4665.

106. Reardon DA, Dresemann G, Taillibert S, Campone M, van den Bent M, Clement P, Blomquist E, Gordower L, Schultz H, Raizer J, et al: Multicentre phase II studies evaluating imatinib plus hydroxyurea in patients with progressive glioblastoma. Br J Cancer 2009, 101:1995-2004.

107. Dresemann G: Imatinib and hydroxyurea in pretreated progressive glioblastoma multiforme: a patient series. Ann Oncol 2005, 16:1702-1708.

108. Dresemann G, Weller M, Rosenthal MA, Wedding U, Wagner W, Engel E, Heinrich B, Mayer-Steinacker R, Karup-Hansen A, Fluge O, et al: Imatinib in combination with hydroxyurea versus hydroxyurea alone as oral therapy in patients with progressive pretreated glioblastoma resistant to standard dose temozolomide. J Neurooncol 2010, 96:393-402.

109. Moreno L, Popov S, Jury A, Al Sarraj S, Jones C, Zacharoulis S: Role of platelet derived growth factor receptor (PDGFR) over-expression and angiogenesis in ependymoma. J Neurooncol 2013, 111:169-176.

110. Tamborini E, Miselli F, Negri T, Lagonigro MS, Staurengo S, Dagrada GP, Stacchiotti S, Pastore E, Gronchi A, Perrone F, et al: Molecular and biochemical analyses of platelet-derived growth factor receptor (PDGFR) B, PDGFRA, and KIT receptors in chordomas. Clin Cancer Res 2006, 12:6920-6928

111. Stacchiotti S, Longhi A, Ferraresi V, Grignani G, Comandone A, Stupp R, Bertuzzi A, Tamborini E, Pilotti S, Messina A, et al: Phase II study of imatinib in advanced chordoma. J Clin Oncol 2012, 30:914-920.

112. Wen PY, Yung WK, Lamborn KR, Norden AD, Cloughesy TF, Abrey LE, Fine HA, Chang SM, Robins HI, Fink K, et al: Phase II study of imatinib mesylate for recurrent meningiomas (North American brain tumor consortium study 01-08). Neuro Oncol 2009, 11:853-860.

113. Reardon DA, Norden AD, Desjardins A, Vredenburgh JJ, Herndon JE 2nd, Coan A, Sampson JH, Gururangan S, Peters KB, McLendon RE, et al: Phase II study of Gleevec (R) plus hydroxyurea (HU) in adults with progressive or recurrent meningioma. J Neurooncol 2012, 106:409-415.

114. Horak P, Wohrer A, Hassler M, Hainfellner J, Preusser M, Marosi C: Imatinib mesylate treatment of recurrent meningiomas in preselected patients: a retrospective analysis. J Neurooncol 2012, 109:323-330.

115. Mukherjee J, Kamnasaran D, Balasubramaniam A, Radovanovic I, Zadeh G, Kiehl TR, Guha A: Human schwannomas express activated plateletderived growth factor receptors and c-kit and are growth inhibited by Gleevec (Imatinib Mesylate). Cancer Res 2009, 69:5099-5107.

116. Sabha N, Au K, Agnihotri S, Singh S, Mangat R, Guha A, Zadeh G: Investigation of the in vitro therapeutic efficacy of nilotinib in immortalized human NF2-null vestibular schwannoma cells. PLoS One 2012, 7:e39412.

117. Ammoun S, Schmid MC, Triner J, Manley P, Hanemann CO: Nilotinib alone or in combination with selumetinib is a drug candidate for neurofibromatosis type 2 . Neuro Oncol 2011, 13:759-766.
118. Malhotra B, Schuetze SM: Dermatofibrosarcoma protruberans treatment with platelet-derived growth factor receptor inhibitor: a review of clinical trial results. Curr Opin Oncol 2012, 24:419-424

119. Patel KU, Szabo SS, Hernandez VS, Prieto VG, Abruzzo LV, Lazar AJ, LopezTerrada D: Dermatofibrosarcoma protuberans COL1A1-PDGFB fusion is identified in virtually all dermatofibrosarcoma protuberans cases when investigated by newly developed multiplex reverse transcription polymerase chain reaction and fluorescence in situ hybridization assays. Hum Pathol 2008, 39:184-193.

120. Greco A, Roccato E, Miranda C, Cleris L, Formelli F, Pierotti MA: Growthinhibitory effect of STI571 on cells transformed by the COL1A1/PDGFB rearrangement. Int J Cancer 2001, 92:354-360.

121. Sjöblom T, Shimizu A, O’Brien KP, Pietras K, Dal Cin P, Buchdunger $E_{1}$ Dumanski JP, Östman A, Heldin C-H: Growth inhibition of dermatofibrosarcoma protuberans tumors by the platelet-derived growth factor receptor antagonist STI571 through induction of apoptosis. Cancer Res 2001, 61:5778-5783.

122. Rubin BP, Schuetze SM, Eary JF, Norwood TH, Mirza S, Conrad EU, Bruckne JD: Molecular targeting of platelet-derived growth factor B by imatinib mesylate in a patient with metastatic dermatofibrosarcoma protuberans. J Clin Oncol 2002, 20:3586-3591.

123. Price VE, Fletcher JA, Zielenska M, Cole W, Viero S, Manson DE, Stuart M, Pappo AS: Imatinib mesylate: an attractive alternative in young children with large, surgically challenging dermatofibrosarcoma protuberans. Pediatr Blood Cancer 2005, 44:511-515.

124. Maki RG, Awan RA, Dixon RH, Jhanwar S, Antonescu CR: Differential sensitivity to imatinib of 2 patients with metastatic sarcoma arising from dermatofibrosarcoma protuberans. Int J Cancer 2002, 100:623-626.

125. Labropoulos SV, Fletcher JA, Oliveira AM, Papadopoulos S, Razis ED: Sustained complete remission of metastatic dermatofibrosarcoma protuberans with imatinib mesylate. Anti-cancer drugs 2005, 16:461-466.

126. Mizutani K, Tamada Y, Hara K, Tsuzuki T, Saeki H, Tamaki K, Matsumoto Y: Imatinib mesylate inhibits the growth of metastatic lung lesions in a patient with dermatofibrosarcoma protuberans. Br J Dermatol 2004, 151:235-237.

127. McArthur GA, Demetri GD, van Oosterom A, Heinrich MC, Debiec-Rychter M Corless CL, Nikolova Z, Dimitrijevic S, Fletcher JA: Molecular and clinical analysis of locally advanced dermatofibrosarcoma protuberans treated with imatinib: imatinib target exploration consortium study B2225. J Clin Oncol 2005, 23:866-873.

128. Heinrich MC, Joensuu H, Demetri GD, Corless CL, Apperley J, Fletcher JA, Soulieres D, Dirnhofer S, Harlow A, Town A, et al: Phase II, open-label study evaluating the activity of imatinib in treating life-threatening malignancies known to be associated with imatinib-sensitive tyrosine kinases. Clin Cancer Res 2008, 14:2717-2725.

129. Rutkowski P, Van Glabbeke M, Rankin CJ, Ruka W, Rubin BP, Debiec-Rychter M, Lazar A, Gelderblom H, Sciot R, Lopez-Terrada D, et al: Imatinib mesylate in advanced dermatofibrosarcoma protuberans: pooled analysis of two phase II clinical trials. J Clin Oncol 2010, 28:1772-1779.

130. Stacchiotti S, Pedeutour F, Negri T, Conca E, Marrari A, Palassini E, Collini P, Keslair F, Morosi C, Gronchi A, et al: Dermatofibrosarcoma protuberansderived fibrosarcoma: clinical history, biological profile and sensitivity to imatinib. Int J Cancer 2011, 129:1761-1772.

131. Kerob D, Porcher $R$, Verola O, Dalle $S$, Maubec E, Aubin F, D'Incan M, Bodokh I, Boulinguez S, Madelaine-Chambrin I, et al: Imatinib mesylate as a preoperative therapy in dermatofibrosarcoma: results of a multicenter phase II study on 25 patients. Clin Cancer Res 2010, 16:3288-3295.

132. Heinrich MC, Corless CL, Demetri GD, Blanke CD, von Mehren $M$, Joensuu $H$, McGreevey LS, Chen CJ, Van den Abbeele AD, Druker BJ, et al: Kinase mutations and imatinib response in patients with metastatic gastrointestinal stromal tumor. J Clin Oncol 2003, 21:4342-4349.

133. Demetri GD, von Mehren M, Blanke CD, Van den Abbeele AD, Eisenberg $B$ Roberts PJ, Heinrich MC, Tuveson DA, Singer S, Janicek M, et al: Efficacy and safety of imatinib mesylate in advanced gastrointestinal stromal tumors. The New England journal of medicine 2002, 347:472-480.

134. Verweij J, Casali PG, Zalcberg J, LeCesne A, Reichardt P, Blay JY, Issels R, van Oosterom A, Hogendoorn PC, Van Glabbeke $M$, et al: Progression-free survival in gastrointestinal stromal tumours with high-dose imatinib: randomised trial. Lancet 2004, 364:1127-1134.

135. Demetri GD, van Oosterom AT, Garrett CR, Blackstein ME, Shah MH, Verweij J, McArthur G, Judson IR, Heinrich MC, Morgan JA, et al: Efficacy and safety 
of sunitinib in patients with advanced gastrointestinal stromal tumour after failure of imatinib: a randomised controlled trial. Lancet 2006, 368:1329-1338.

136. Demetri GD, Casali PG, Blay JY, von Mehren M, Morgan JA, Bertulli R, RayCoquard I, Cassier P, Davey M, Borghaei $\mathrm{H}$, et al: A phase I study of singleagent nilotinib or in combination with imatinib in patients with imatinib-resistant gastrointestinal stromal tumors. Clin Cancer Res 2009, 15:5910-5916.

137. Montemurro M, Schoffski $P$, Reichardt P, Gelderblom H, Schutte J, Hartmann JT, von Moos R, Seddon B, Joensuu H, Wendtner CM, et al: Nilotinib in the treatment of advanced gastrointestinal stromal tumours resistant to both imatinib and sunitinib. Eur J Cancer 2009, 45:2293-2297.

138. Saglio G, Kim DW, Issaragrisil S, le Coutre P, Etienne G, Lobo C, Pasquini R, Clark RE, Hochhaus A, Hughes TP, et al: Nilotinib versus imatinib for newly diagnosed chronic myeloid leukemia. N Engl J Med 2010, 362:2251-2259.

139. Betsholtz C, Westermark B, Ek B, Heldin C-H: Coexpression of a PDGF-like growth factor and PDGF receptors in a human osteosarcoma cell line: Implications for autocrine receptor activation. Cell 1984, 39:447-457.

140. Smits A, Funa K, Vassbotn FS, Beausang-Linder M, af Ekenstam F, Heldin C-H, Westermark B, Nistér M: Expression of platelet-derived growth factor and its receptors in proliferative disorders of fibroblastic origin. Am J Pathol 1992, 140:639-648

141. Wang J, Coltrera MD, Gown AM: Cell proliferation in human soft tissue tumors correlates with platelet-derived growth factor B chain expression: an immunohistochemical and in situ hybridization study. Cancer Res 1994, 54:560-564.

142. Kubo T, Piperdi S, Rosenblum J, Antonescu CR, Chen W, Kim HS, Huvos AG Sowers R, Meyers PA, Healey JH, Gorlick R: Platelet-derived growth factor receptor as a prognostic marker and a therapeutic target for imatinib mesylate therapy in osteosarcoma. Cancer 2008, 112:2119-2129.

143. Ho AL, Vasudeva SD, Lae M, Saito T, Barbashina V, Antonescu CR, Ladanyi M, Schwartz GK: PDGF receptor alpha is an alternative mediator of rapamycin-induced Akt activation: implications for combination targeted therapy of synovial sarcoma. Cancer Res 2012, 72:4515-4525.

144. Zwerner JP, May WA: Dominant negative PDGF-C inhibits growth of Ewing family tumor cell lines. Oncogene 2002, 21:3847-3854.

145. Ehnman M, Missiaglia E, Folestad E, Selfe J, Strell C, Thway K, Brodin B, Pietras K, Shipley J, Ostman A, Eriksson U: Distinct effects of ligand-induced PDGFRa and PDGFR $\beta$ signaling in the human rhabdomyosarcoma tumor cell and stroma cell compartments. Cancer Res 2013, 73:2139-2149.

146. Taniguchi E, Nishijo K, McCleish AT, Michalek JE, Grayson MH, Infante AJ, Abboud HE, Legallo RD, Qualman SJ, Rubin BP, Keller C: PDGFR-A is a therapeutic target in alveolar rhabdomyosarcoma. Oncogene 2008, 27:6550-6560

147. Blandford MC, Barr FG, Lynch JC, Randall RL, Qualman SJ, Keller C: Rhabdomyosarcomas utilize developmental, myogenic growth factors for disease advantage: a report from the children's oncology group. Pediatr Blood Cancer 2006, 46:329-338.

148. Armistead PM, Salganick J, Roh JS, Steinert DM, Patel S, Munsell M, ElNaggar AK, Benjamin RS, Zhang W, Trent JC: Expression of receptor tyrosine kinases and apoptotic molecules in rhabdomyosarcoma: correlation with overall survival in 105 patients. Cancer 2007, 110:2293-2303.

149. van der Graaf WT, Blay JY, Chawla SP, Kim DW, Bui-Nguyen B, Casali PG, Schoffski P, Aglietta M, Staddon AP, Beppu Y, et al: Pazopanib for metastatic soft-tissue sarcoma (PALETTE): a randomised, double-blind, placebo-controlled phase 3 trial. Lancet 2012, 379:1879-1886.

150. Asa SA, Murai A, Murakami M, Hoshino Y, Mori T, Maruo K, Khater A, ElSawak A, El-Aziz EA, Yanai T, Sakai H: Expression of platelet-derived growth factor and its receptors in spontaneous canine hemangiosarcoma and cutaneous hemangioma. Histol Histopathol 2012, 27:601-607.

151. Dickerson EB, Marley K, Edris W, Tyner JW, Schalk V, Macdonald V, Loriaux M, Druker BJ, Helfand SC: Imatinib and dasatinib inhibit hemangiosarcoma and implicate PDGFR- $\beta$ and Src in tumor growth. Trans/ Oncol 2013, 6:158-168.

152. Golub TR, Barker GF, Lovett M, Gilliland DG: Fusion of PDGF receptor $\beta$ to a novel ets-like gene, tel, in chronic myelomonocytic leukemia with $\mathrm{t}$ $(5 ; 12)$ chromosomal translocation. Cell 1994, 77:307-316.

153. Magnusson MK, Meade KE, Brown KE, Arthur DC, Krueger LA, Barrett AJ, Dunbar CE: Rabaptin-5 is a novel fusion partner to platelet-derived growth factor $\beta$ receptor in chronic myelomonocytic leukemia. Blood 2001, 98:2518-2525.
154. Ross TS, Gilliland DG: Transforming properties of the Huntingtin interacting protein 1/platelet-derived growth factor beta receptor fusion protein. J Biol Chem 1999, 274:22328-22336.

155. Schwaller J, Anastasiadou E, Cain D, Kutok J, Wojiski S, Williams IR, LaStarza R, Crescenzi B, Sternberg DW, Andreasson P, et al: H4(D10S170), a gene frequently rearranged in papillary thyroid carcinoma, is fused to the platelet-derived growth factor receptor $\beta$ gene in atypical chronic myeloid leukemia with t (5;10) (q33; q22). Blood 2001, 97:3910-3918.

156. Medves S, Duhoux FP, Ferrant A, Toffalini F, Ameye G, Libouton JM, Poirel HA, Demoulin JB: KANK1, a candidate tumor suppressor gene, is fused to PDGFRB in an imatinib-responsive myeloid neoplasm with severe thrombocythemia. Leukemia: official journal of the Leukemia Society of America, Leukemia Research Fund, UK 2010, 24:1052-1055.

157. Cools J, DeAngelo DJ, Gotlib J, Stover EH, Legare RD, Cortes J, Kutok J, Clark J, Galinsky I, Griffin JD, et al: A tyrosine kinase created by fusion of the PDGFRA and FIP1L1 genes as a therapeutic target of imatinib in idiopathic hypereosinophilic syndrome. N Engl J Med 2003, 348:1201-1214.

158. Griffin JH, Leung J, Bruner RJ, Caligiuri MA, Briesewitz R: Discovery of a fusion kinase in EOL-1 cells and idiopathic hypereosinophilic syndrome. Proc Natl Acad Sci USA 2003, 100:7830-7835.

159. Pardanani A, Ketterling RP, Brockman SR, Flynn HC, Paternoster SF, Shearer BM, Reeder TL, Li CY, Cross NC, Cools J, et al: CHIC2 deletion, a surrogate for FIP1L1-PDGFRA fusion, occurs in systemic mastocytosis associated with eosinophilia and predicts response to imatinib mesylate therapy. Blood 2003, 102:3093-3096.

160. Elling C, Erben P, Walz C, Frickenhaus M, Schemionek M, Stehling M, Serve $H$, Cross NC, Hochhaus A, Hofmann WK, et al: Novel imatinib-sensitive PDGFRAactivating point mutations in hypereosinophilic syndrome induce growth factor independence and leukemia-like disease. Blood 2011, 117:2935-2943.

161. Toffalini F, Hellberg C, Demoulin J-B: Critical role of the platelet-derived growth factor receptor (PDGFR) $\beta$ transmembrane domain in the TELPDGFR $\beta$ cytosolic oncoprotein. J Biol Chem 2010, 285:12268-12278.

162. Stover EH, Chen J, Folens $C$, Lee BH, Mentens N, Marynen P, Williams IR, Gilliland DG, Cools J: Activation of FIP1L1-PDGFRa requires disruption of the juxtamembrane domain of PDGFRa and is FIP1L1-independent. Proc Natl Acad Sci USA 2006, 103:8078-8083.

163. Toffalini F, Kallin A, Vandenberghe P, Pierre P, Michaux L, Cools J, Demoulin JB: The fusion proteins TEL-PDGFR $\beta$ and FIP1L1-PDGFRa escape ubiquitination and degradation. Haematologica 2009, 94:1085-1093.

164. Cools J, Stover EH, Boulton CL, Gotlib J, Legare RD, Amaral SM, Curley DP, Duclos N, Rowan R, Kutok JL, et al: PKC412 overcomes resistance to imatinib in a murine model of FIP1L1-PDGFRa-induced myeloproliferative disease. Cancer Cell 2003, 3:459-469.

165. Klion AD, Noel P, Akin C, Law MA, Gilliland DG, Cools J, Metcalfe DD, Nutman TB: Elevated serum tryptase levels identify a subset of patients with a myeloproliferative variant of idiopathic hypereosinophilic syndrome associated with tissue fibrosis, poor prognosis, and imatinib responsiveness. Blood 2003, 101:4660-4666.

166. Fukushima K, Matsumura I, Ezoe S, Tokunaga M, Yasumi M, Satoh $Y$, Shibayama H, Tanaka H, Iwama A, Kanakura Y: FIP1L1-PDGFRa imposes eosinophil lineage commitment on hematopoietic stem/progenitor cells. J Biol Chem 2009, 284:7719-7732.

167. Buitenhuis M, Verhagen LP, Cools J, Coffer PJ: Molecular mechanisms underlying FIP1L1-PDGFRA-mediated myeloproliferation. Cancer Res 2007, 67:3759-3766

168. Montano-Almendras CP, Essaghir A, Schoemans H, Varis I, Noel LA, Velghe Al, Latinne D, Knoops L, Demoulin JB: ETV6-PDGFRB and FIP1L1-PDGFRA stimulate human hematopoietic progenitor cell proliferation and differentiation into eosinophils: the role of nuclear factor-kB. Haematologica 2012, 97:1064-1072.

169. Apperley JF, Gardembas M, Melo JV, Russell-Jones R, Bain BJ, Baxter EJ, Chase A, Chessells JM, Colombat M, Dearden CE, et al: Response to imatinib mesylate in patients with chronic myeloproliferative diseases with rearrangements of the platelet-derived growth factor receptor beta. $N$ Engl J Med 2002, 347:481-487.

170. Gleich GJ, Leiferman KM, Pardanani A, Tefferi A, Butterfield JH: Treatment of hypereosinophilic syndrome with imatinib mesilate. Lancet 2002, 359:1577-1578.

171. Cortes J, Ault P, Koller C, Thomas D, Ferrajoli A, Wierda W, Rios MB, Letvak L, Kaled ES, Kantarjian H: Efficacy of imatinib mesylate in the treatment of idiopathic hypereosinophilic syndrome. Blood 2003, 101:4714-4716. 
172. Ault P, Cortes J, Koller C, Kaled ES, Kantarjian H: Response of idiopathic hypereosinophilic syndrome to treatment with imatinib mesylate. Leuk Res 2002, 26:881-884

173. Pardanani A, Reeder T, Porrata LF, Li CY, Tazelaar HD, Baxter EJ, Witzig TE, Cross NC, Tefferi A: Imatinib therapy for hypereosinophilic syndrome and other eosinophilic disorders. Blood 2003, 101:3391-3397.

174. Chen J, Wall NR, Kocher K, Duclos N, Fabbro D, Neuberg D, Griffin JD, Shi Y, Gilliland DG: Stable expression of small interfering RNA sensitizes TELPDGF $\beta R$ to inhibition with imatinib or rapamycin. J Clin Invest 2004, 113:1784-1791.

175. Lierman E, Folens C, Stover EH, Mentens N, Van Miegroet H, Scheers W, Boogaerts $M$, Vandenberghe $\mathrm{P}$, Marynen $\mathrm{P}$, Cools J: Sorafenib is a potent inhibitor of FIP1L1-PDGFRa and the imatinib-resistant FIP1L1-PDGFRa T674I mutant. Blood 2006, 108:1374-1376.

176. Stover $\mathrm{EH}$, Chen J, Lee BH, Cools J, McDowell E, Adelsperger J, Cullen D, Coburn A, Moore SA, Okabe R, et al: The small molecule tyrosine kinase inhibitor AMN107 inhibits TEL-PDGFRß and FIP1L1-PDGFRa in vitro and in vivo. Blood 2005, 106:3206-3213.

177. von Bubnoff N, Gorantla SP, Engh RA, Oliveira TM, Thone S, Aberg E, Peschel C, Duyster J: The low frequency of clinical resistance to PDGFR inhibitors in myeloid neoplasms with abnormalities of PDGFRA might be related to the limited repertoire of possible PDGFRA kinase domain mutations in vitro. Oncogene 2011, 30:933-943.

178. Daynes RA, Dowell T, Araneo BA: Platelet-derived growth factor is a potent biologic response modifier of T cells. J Exp Med 1991, 174:1323-1333.

179. Gersuk GM, Westermark B, Mohabeer AJ, Challita PM, Pattamakom S, Pattengale PK: Inhibition of human natural killer cell activity by plateletderived growth factor (PDGF): III membrane binding studies and differential biological effect of recombinant PDGF isoforms. Scand J Immunol 1991, 33:521-532.

180. Yang J, Liu X, Nyland SB, Zhang R, Ryland LK, Broeg K, Baab KT, Jarbadan $N R$, Irby $R$, Loughran TP Jr: Platelet-derived growth factor mediates survival of leukemic large granular lymphocytes via an autocrine regulatory pathway. Blood 2010, 115:51-60.

181. Laimer D, Dolznig H, Kollmann K, Vesely PW, Schlederer M, Merkel O, Schiefer Al, Hassler MR, Heider S, Amenitsch L, et al: PDGFR blockade is a rational and effective therapy for NPM-ALK-driven lymphomas. Nat Med 2012, 18:1699-1704.

182. Ko YJ, Small EJ, Kabbinavar F, Chachoua A, Taneja S, Reese D, DePaoli A, Hannah A, Balk SP, Bubley GJ: A multi-institutional phase ii study of SU101, a platelet-derived growth factor receptor inhibitor, for patients with hormone-refractory prostate cancer. Clin Cancer Res 2001, 7:800-805.

183. Singh D, Febbo PG, Ross K, Jackson DG, Manola J, Ladd C, Tamayo P, Renshaw AA, D'Amico AV, Richie JP, et al: Gene expression correlates of clinical prostate cancer behavior. Cancer Cell 2002, 1:203-209.

184. Ustach CV, Taube ME, Hurst NJ Jr, Bhagat S, Bonfil RD, Cher ML, Schuger L, Kim HR: A potential oncogenic activity of platelet-derived growth factor D in prostate cancer progression. Cancer Res 2004, 64:1722-1729.

185. Conley-LaComb MK, Huang W, Wang S, Shi D, Jung YS, Najy A, Fridman R, Bonfil RD, Cher ML, Chen YQ, Kim HR: PTEN regulates PDGF ligand switch for beta-PDGFR signaling in prostate cancer. Am J Pathol 2012, 180:1017-1027.

186. Kong D, Banerjee S, Ahmad A, Li Y, Wang Z, Sethi S, Sarkar FH: Epithelial to mesenchymal transition is mechanistically linked with stem cell signatures in prostate cancer cells. PLoS One 2010, 5:e12445.

187. Najy AJ, Won JJ, Movilla LS, Kim HR: Differential tumorigenic potential and matriptase activation between PDGF B versus PDGF D in prostate cancer. Mol Cancer Res 2012, 10:1087-1097.

188. Huang W, Fridman Y, Bonfil RD, Ustach CV, Conley-LaComb MK, Wiesner C, Saliganan A, Cher ML, Kim HR: A novel function for platelet-derived growth factor D: induction of osteoclastic differentiation for intraosseous tumor growth. Oncogene 2012, 31:4527-4535.

189. Dolloff NG, Russell MR, Loizos N, Fatatis A: Human bone marrow activates the Akt pathway in metastatic prostate cells through transactivation of the alpha-platelet-derived growth factor receptor. Cancer Res 2007, 67:555-562.

190. Russell MR, Jamieson WL, Dolloff NG, Fatatis A: The a-receptor for plateletderived growth factor as a target for antibody-mediated inhibition of skeletal metastases from prostate cancer cells. Oncogene 2009, 28:412-421.
191. Park YH, Seo SY, Ha M, Ku JH, Kim HH, Kwak C: Inhibition of prostate cancer using RNA interference-directed knockdown of platelet-derived growth factor receptor. Urology 2011, 77:1509. e1509-1515.

192. Russell MR, Liu Q, Lei H, Kazlauskas A, Fatatis A: The a-receptor for plateletderived growth factor confers bone-metastatic potential to prostate cancer cells by ligand- and dimerization-independent mechanisms. Cancer Res 2010, 70:4195-4203.

193. Uehara H, Kim SJ, Karashima T, Shepherd DL, Fan D, Tsan R, Killion Jل, Logothetis C, Mathew P, Fidler IJ: Effects of blocking platelet-derived growth factor-receptor signaling in a mouse model of experimental prostate cancer bone metastases. J Natl Cancer Inst 2003, 95:458-470.

194. Kim SJ, Uehara H, Yazici S, Langley RR, He J, Tsan R, Fan D, Killion JJ, Fidler IJ: Simultaneous blockade of platelet-derived growth factor-receptor and epidermal growth factor-receptor signaling and systemic administration of paclitaxel as therapy for human prostate cancer metastasis in bone of nude mice. Cancer Res 2004, 64:4201-4208.

195. Mathew P, Thall PF, Jones D, Perez C, Bucana C, Troncoso P, Kim SJ, Fidler IJ, Logothetis C: Platelet-derived growth factor receptor inhibitor imatinib mesylate and docetaxel: a modular phase I trial in androgenindependent prostate cancer. J Clin Oncol 2004, 22:3323-3329.

196. Mathew P, Thall PF, Bucana CD, Oh WK, Morris MJ, Jones DM, Johnson MM, Wen S, Pagliaro LC, Tannir NM, et al: Platelet-derived growth factor receptor inhibition and chemotherapy for castration-resistant prostate cancer with bone metastases. Clin Cancer Res 2007, 13:5816-5824.

197. Mathew P, Thall PF, Wen S, Bucana C, Jones D, Horne E, Oh WK, Morris MJ, Lee YC, Logothetis CJ, et al: Dynamic change in phosphorylated plateletderived growth factor receptor in peripheral blood leukocytes following docetaxel therapy predicts progression-free and overall survival in prostate cancer. Br J Cancer 2008, 99:1426-1432

198. Najy AJ, Jung YS, Won JJ, Conley-LaComb MK, Saliganan A, Kim CJ, Heath E, Cher ML, Bonfil RD, Kim HR: Cediranib inhibits both the intraosseous growth of PDGF D-positive prostate cancer cells and the associated bone reaction. Prostate 2012, 72:1328-1338.

199. Gotzmann J, Fischer AN, Zojer M, Mikula M, Proell V, Huber H, Jechlinger M, Waerner T, Weith A, Beug H, Mikulits W: A crucial function of PDGF in TGF$\beta$-mediated cancer progression of hepatocytes. Oncogene 2006, 25:3170-3185

200. Fischer AN, Fuchs E, Mikula M, Huber $H$, Beug $H$, Mikulits W: PDGF essentially links TGF- $\beta$ signaling to nuclear $\beta$-catenin accumulation in hepatocellular carcinoma progression. Oncogene 2007, 26:3395-3405.

201. Llovet JM, Ricci S, Mazzaferro V, Hilgard P, Gane E, Blanc JF, de Oliveira AC, Santoro A, Raoul JL, Forner A, et al: Sorafenib in advanced hepatocellular carcinoma. N Engl J Med 2008, 359:378-390.

202. Cheng AL, Kang YK, Chen Z, Tsao CJ, Qin S, Kim JS, Luo R, Feng J, Ye S, Yang TS, et al: Efficacy and safety of sorafenib in patients in the AsiaPacific region with advanced hepatocellular carcinoma: a phase III randomised, double-blind, placebo-controlled trial. Lancet Oncol 2009, 10:25-34.

203. Boonjaraspinyo S, Boonmars T, Wu Z, Loilome W, Sithithaworn P, Nagano Pinlaor S, Yongvanit P, Nielsen PS, Pairojkul C, Khuntikeo N: Platelet-derived growth factor may be a potential diagnostic and prognostic marker for cholangiocarcinoma. Tumour Biol 2012, 33:1785-1802.

204. Sugiyama H, Onuki K, Ishige K, Baba N, Ueda T, Matsuda S, Takeuchi K, Onodera M, Nakanuma Y, Yamato $\mathrm{M}$, et al: Potent in vitro and in vivo antitumor activity of sorafenib against human intrahepatic cholangiocarcinoma cells. J Gastroenterol 2011, 46:779-789.

205. Fingas CD, Bronk SF, Werneburg NW, Mott JL, Guicciardi ME, Cazanave SC, Mertens JC, Sirica AE, Gores GJ: Myofibroblast-derived PDGF-BB promotes Hedgehog survival signaling in cholangiocarcinoma cells. Hepatology 2011, 54:2076-2088.

206. Fingas CD, Mertens JC, Razumilava N, Bronk SF, Sirica AE, Gores GJ: Targeting PDGFR- $\beta$ in cholangiocarcinoma. Liver Int 2012, 32:400-409.

207. Kawai T, Hiroi S, Torikata C: Expression in lung carcinomas of plateletderived growth factor and its receptors. Lab Invest 1997, 77:431-436.

208. Fitzer-Attas C, Feldman M, Eisenbach L: Expression of functionally intact PDGF-a receptors in highly metastatic 3LL Lewis lung carcinoma cells. Int J Cancer 1993, 53:315-322.

209. Antoniades HN, Galanopoulos T, Neville-Golden J, O'Hara CJ: Malignant epithelial cells in primary human lung carcinomas coexpress in vivo platelet-derived growth factor (PDGF) and PDGF receptor mRNAs and their protein products. Proc Natl Acad Sci USA 1992, 89:3942-3946. 
210. Tsao AS, Wei W, Kuhn E, Spencer L, Solis LM, Suraokar M, Lee JJ, Hong WK, Wistuba II: Immunohistochemical overexpression of platelet-derived growth factor receptor-beta (PDGFR- $\beta$ ) is associated with PDGFRB gene copy number gain in sarcomatoid non-small-cell lung cancer. Clin Lung Cancer 2011, 12:369-374.

211. Donnem T, Al-Saad S, Al-Shibli K, Andersen S, Busund LT, Bremnes RM: Prognostic impact of platelet-derived growth factors in non-small cell lung cancer tumor and stromal cells. J Thorac Oncol 2008, 3:963-970.

212. Laing N, McDermott B, Wen S, Yang D, Lawson D, Collins M, Reimer C, Hall $\mathrm{PA}$, Andersen $\mathrm{H}$, Snaith $\mathrm{M}$, et al: Inhibition of platelet-derived growth factor receptor a by MEDI-575 reduces tumor growth and stromal fibroblast content in a model of non-small cell lung cancer. Mol Pharmacol 2013 83:1247-1256.

213. Reinmuth N, Liersch R, Raedel M, Fehrmann F, Fehrmann N, Bayer M, Schwoeppe C, Kessler T, Berdel W, Thomas M, Mesters RM: Combined antiPDGFRa and PDGFR $\beta$ targeting in non-small cell lung cancer. Int J Cancer 2009, 124:1535-1544.

214. Huang CH, Williamson SK, Van Veldhuizen PJ, Hsueh CT, Allen A, Tawfik O, Wick J, Smith H, Uypeckcuat AM, Mayo M, Kelly K: Potential role of platelet-derived growth factor receptor inhibition using imatinib in combination with docetaxel in the treatment of recurrent non-small cell lung cancer. J Thorac Oncol 2011, 6:372-377.

215. Ping G, Hui-Min W, Wei-Min W, Bao-Hui H: Sunitinib in pretreated advanced non-small-cell lung carcinoma: a primary result from Asian population. Med Oncol 2011, 28:578-583.

216. Bhardwaj B, Klassen J, Cossette N, Sterns E, Tuck A, Deeley R, Sengupta S, Elliott B: Localization of platelet-derived growth factor $\beta$ receptor expression in the periepithelial stroma of human breast carcinoma. Clin Cancer Res 1996, 2:773-782.

217. Coltrera MD, Wang J, Porter PL, Gown AM: Expression of platelet-derived growth factor B-chain and the platelet-derived growth factor receptor $\beta$ subunit in human breast tissue and breast carcinoma. Cancer Res 1995, 55:2703-2708.

218. Seymour L, Bezwoda WR: Positive immunostaining for platelet derived growth factor (PDGF) is an adverse prognostic factor in patients with advanced breast cancer. Breast Cancer Res Treat 1994, 32:229-233.

219. Carvalho I, Milanezi F, Martins A, Reis RM, Schmitt F: Overexpression of platelet-derived growth factor receptor a in breast cancer is associated with tumour progression. Breast Cancer Res 2005, 7:R788-R795.

220. Campbell Cl, Moorehead RA: Mammary tumors that become independent of the type I insulin-like growth factor receptor express elevated levels of platelet-derived growth factor receptors. BMC cancer 2011, 11:480

221. Weigel MT, Dahmke L, Schem C, Bauerschlag DO, Weber K, Niehoff P, Bauer $M$, Strauss A, Jonat W, Maass N, Mundhenke C: In vitro effects of imatinib mesylate on radiosensitivity and chemosensitivity of breast cancer cells. BMC cancer 2010, 10:412.

222. Devarajan E, Song YH, Krishnappa S, Alt E: Epithelial-mesenchymal transition in breast cancer lines is mediated through PDGF-D released by tissue-resident stem cells. Int J Cancer 2012, 131:1023-1031.

223. Weigel MT, Ghazoui Z, Dunbier A, Pancholi S, Dowsett M, Martin LA: Preclinical and clinical studies of estrogen deprivation support the PDGF/Abl pathway as a novel therapeutic target for overcoming endocrine resistance in breast cancer. Breast Cancer Res 2012, 14:R78.

224. Lindmark G, Sundberg C, Glimelius B, Påhlman L, Rubin K, Gerdin B: Stromal expression of platelet-derived growth factor $\beta$-receptor and plateletderived growth factor B-chain in colorectal cancer. Lab Invest 1993, 69:682-689.

225. Sundberg C, Ljungström M, Lindmark G, Gerdin B, Rubin K: Microvascular pericytes express platelet-derived growth factor- $\beta$ receptors in human healing wounds and colorectal adenocarcinoma. Am J Pathol 1993, 143:1377-1388.

226. Steller EJ, Ritsma L, Raats DA, Hoogwater FJ, Emmink BL, Govaert KM, Laoukili J, Rinkes $I H$, van Rheenen J, Kranenburg $O$ : The death receptor CD95 activates the cofilin pathway to stimulate tumour cell invasion. EMBO Rep 2011, 12:931-937.

227. Wehler TC, Frerichs K, Graf C, Drescher D, Schimanski K, Biesterfeld S, Berger MR, Kanzler $S$, Junginger T, Galle PR, et al: PDGFRa/ $\beta$ expression correlates with the metastatic behavior of human colorectal cancer: a possible rationale for a molecular targeting strategy. Oncol Rep 2008, 19:697-704.

228. Kitadai Y, Sasaki T, Kuwai T, Nakamura T, Bucana CD, Hamilton SR, Fidler IJ: Expression of activated platelet-derived growth factor receptor in stromal cells of human colon carcinomas is associated with metastatic potential. Int J Cancer 2006, 119:2567-2574.

229. Steller EJ, Raats DA, Koster J, Rutten B, Govaert KM, Emmink BL, Snoeren N, van Hooff SR, Holstege FC, Maas C, et al: PDGFRB promotes liver metastasis formation of mesenchymal-like colorectal tumor cells. Neoplasia 2013, 15:204-217.

230. Honda M, Kanno T, Fujita Y, Gotoh A, Nakano T, Nishizaki T: Mesothelioma cell proliferation through autocrine activation of PDGF- $\beta \beta$ receptor. Cell Physiol Biochem 2012, 29:667-674.

231. Ghanem M, Nijman R, Safan M, van der Kwast T, Vansteenbrugge G: Expression and prognostic value of platelet-derived growth factor-AA and its receptor $a$ in nephroblastoma. BJU Int 2010, 106:1389-1393.

232. Seymour L, Dajee D, Bezwoda WR: Tissue platelet derived-growth factor (PDGF) predicts for shortened survival and treatment failure in advanced breast cancer. Breast Cancer Res Treat 1993, 26:247-252.

233. Henriksen R, Funa K, Wilander E, Bäckström T, Ridderheim M, Öberg K: Expression and prognostic significance of platelet-derived growth factor and its receptors in epithelial ovarian neoplasms. Cancer Res 1993, 53:4550-4554.

234. Takanami I, Imamura T, Yamamoto Y, Kodaira S: Usefulness of plateletderived growth factor as a prognostic factor in pulmonary adenocarcinoma. J Surg Oncol 1995, 58:40-43.

235. Matsui T, Sano K, Tsukamoto T, Ito M, Takaishi T, Nakata H, Nakamura H, Chihara K: Human neuroblastoma cells express $\alpha$ and $\beta$ platelet-derived growth factor receptors coupling with neurotrophic and chemotactic signaling. J Clin Invest 1993, 92:1153-1160.

236. Uccini S, Mannarino O, McDowell HP, Pauser U, Vitali R, Natali PG, Altavista $P$, Andreano T, Coco S, Boldrini R, et al: Clinical and molecular evidence for c-kit receptor as a therapeutic target in neuroblastic tumors. Clin Cancer Res 2005, 11:380-389.

237. Bond M, Bernstein ML, Pappo A, Schultz KR, Krailo M, Blaney SM, Adamson PC: A phase II study of imatinib mesylate in children with refractory or relapsed solid tumors: a children's oncology group study. Pediatr Blood Cancer 2008, 50:254-258.

238. Xie J, Aszterbaum M, Zhang X, Bonifas JM, Zachary C, Epstein E, McCormick F: A role of PDGFRa in basal cell carcinoma proliferation. Proc Natl Acad Sci U S A 2001, 98:9255-9259.

239. Basciani S, De Luca G, Dolci S, Brama M, Arizzi M, Mariani S, Rosano G, Spera $\mathrm{G}$, Gnessi L: Platelet-derived growth factor receptor $\beta$-subtype regulates proliferation and migration of gonocytes. Endocrinology 2008, 149:6226-6235

240. Froehner M, Beuthien-Baumann B, Dittert DD, Schuler U, Wirth MP: Lack of efficacy of imatinib in a patient with metastatic leydig cell tumor. Cancer Chemother Pharmacol 2006, 58:716-718.

241. Castillo-Avila W, Piulats JM, Garcia Del Muro X, Vidal A, Condom E, Casanovas O, Mora J, Germa JR, Capella G, Villanueva A, Vinals F: Sunitinib inhibits tumor growth and synergizes with cisplatin in orthotopic models of cisplatin-sensitive and cisplatin-resistant human testicular germ cell tumors. Clin Cancer Res 2009, 15:3384-3395.

242. Malkomes P, Oppermann E, Bechstein WO, Holzer K: Significantly high expression of platelet-derived growth factor (PDGF) in benign nodules of the thyroid: relevance in the development of goitre recurrence? Langenbecks Arch Surg 2011, 396:1165-1172.

243. Kerbel RS: Tumor angiogenesis. N Engl J Med 2008, 358:2039-2049.

244. Sennino B, Falcon BL, McCauley D, Le T, McCauley T, Kurz JC, Haskell A Epstein DM, McDonald DM: Sequential loss of tumor vessel pericytes and endothelial cells after inhibition of platelet-derived growth factor B by selective aptamer AX102. Cancer Res 2007, 67:7358-7367.

245. Kuhnert F, Tam BY, Sennino B, Gray JT, Yuan J, Jocson A, Nayak NR, Mulligan $\mathrm{RC}, \mathrm{McD}$ nald DM, Kuo CJ: Soluble receptor-mediated selective inhibition of VEGFR and PDGFRß signaling during physiologic and tumor angiogenesis. Proc Natl Acad Sci USA 2008, 105:10185-10190.

246. Erber R, Thurnher A, Katsen AD, Groth G, Kerger H, Hammes HP, Menger MD, Ullrich A, Vajkoczy P: Combined inhibition of VEGF and PDGF signaling enforces tumor vessel regression by interfering with pericytemediated endothelial cell survival mechanisms. Faseb J 2004, 18:338-340.

247. Hasumi Y, Klosowska-Wardega A, Furuhashi M, Östman A, Heldin C-H, Hellberg $C$ : Identification of a subset of pericytes that respond to combination therapy targeting PDGF and VEGF signaling. Int J Cancer 2007, 121:2606-2614.

248. Bergers G, Song S, Meyer-Morse N, Bergsland E, Hanahan D: Benefits of targeting both pericytes and endothelial cells in the tumor vasculature with kinase inhibitors. J Clin Invest 2003, 111:1287-1295. 
249. Taeger J, Moser C, Hellerbrand C, Mycielska ME, Glockzin G, Schlitt HJ, Geissler EK, Stoeltzing O, Lang SA: Targeting FGFR/PDGFR/VEGFR impairs tumor growth, angiogenesis, and metastasis by effects on tumor cells, endothelial cells, and pericytes in pancreatic cancer. Mol Cancer Ther 2011, 10:2157-2167.

250. Crawford Y, Kasman I, Yu L, Zhong C, Wu X, Modrusan Z, Kaminker J, Ferrara $\mathrm{N}$ : PDGF-C mediates the angiogenic and tumorigenic properties of fibroblasts associated with tumors refractory to anti-VEGF treatment. Cancer Cell 2009, 15:21-34.

251. McCarty MF, Somcio RJ, Stoeltzing O, Wey J, Fan F, Liu W, Bucana C, Ellis LM: Overexpression of PDGF-BB decreases colorectal and pancreatic cancer growth by increasing tumor pericyte content. J Clin Invest 2007, 117:2114-2122

252. Ho IA, Toh HC, Ng WH, Teo YL, Guo CM, Hui KM, Lam PY: Human bone marrow-derived mesenchymal stem cells suppress human glioma growth through inhibition of angiogenesis. Stem Cells 2013, 31:146-155.

253. Xue $Y$, Lim S, Yang Y, Wang $Z$, Jensen LD, Hedlund EM, Andersson $P$ Sasahara M, Larsson O, Galter D, et al: PDGF-BB modulates hematopoiesis and tumor angiogenesis by inducing erythropoietin production in stromal cells. Nat Med 2012, 18:100-110.

254. Ding W, Knox TR, Tschumper RC, Wu W, Schwager SM, Boysen JC, Jelinek DF, Kay NE: Platelet-derived growth factor (PDGF)-PDGF receptor interaction activates bone marrow-derived mesenchymal stromal cells derived from chronic lymphocytic leukemia: implications for an angiogenic switch. Blood 2010, 116:2984-2993.

255. Cao R, Björndahl MA, Religa P, Clasper S, Garvin S, Galter D, Meister B, Ikomi $F$, Tritsaris K, Dissing $S$, et al: PDGF-BB induces intratumoral lymphangiogenesis and promotes lymphatic metastasis. Cancer Cell 2004, 6:333-345.

256. Kodama M, Kitadai Y, Sumida T, Ohnishi M, Ohara E, Tanaka M, Shinagawa K, Tanaka S, Yasui W, Chayama K: Expression of platelet-derived growth factor (PDGF)-B and PDGF-receptor $\beta$ is associated with lymphatic metastasis in human gastric carcinoma. Cancer Sci 2010, 101:1984-1989.

257. Zhang J, Wang P, Dykstra M, Gelebart P, Williams D, Ingham R, Adewuyi EE, Lai R, McMullen T: Platelet-derived growth factor receptor-a promotes lymphatic metastases in papillary thyroid cancer. J Pathol 2012, 228:241-250.

258. Pietras K, Östman A: Hallmarks of cancer: interactions with the tumor stroma. Exp Cell Res 2010, 316:1324-1331.

259. Hanahan D, Coussens LM: Accessories to the crime: functions of cells recruited to the tumor microenvironment. Cancer Cell 2012, 21:309-322.

260. Forsberg K, Valyi-Nagy I, Heldin C-H, Herlyn M, Westermark B: Platelet-derived growth factor (PDGF) in oncogenesis: development of a vascular connective tissue stroma in xenotransplanted human melanoma producing PDGF-BB. Proc Natl Acad Sci U S A 1993, 90:393-397.

261. Skobe M, Fusenig NE: Tumorigenic conversion of immortal human keratinocytes through stromal cell activation. Proc Natl Acad Sci U S A 1998, 95:1050-1055.

262. Cheng J, Ye H, Liu Z, Xu C, Zhang Z, Liu Y, Sun Y: Platelet-derived growth factor-BB accelerates prostate cancer growth by promoting the proliferation of mesenchymal stem cells. J Cell Biochem 2013, 114:1510-1518.

263. Shao Z-M, Nguyen M, Barsky SH: Human breast carcinoma desmoplasia is PDGF initiated. Oncogene 2000, 19:4337-4345.

264. Tejada ML, Yu L, Dong J, Jung K, Meng G, Peale FV, Frantz GD, Hall L, Liang $X$, Gerber HP, Ferrara N: Tumor-driven paracrine platelet-derived growth factor receptor a signaling is a key determinant of stromal cell recruitment in a model of human lung carcinoma. Clin Cancer Res 2006, $12: 2676-2688$

265. Campbell JS, Hughes SD, Gilbertson DG, Palmer TE, Holdren MS, Haran AC, Odell MM, Bauer RL, Ren HP, Haugen HS, et al: Platelet-derived growth factor $C$ induces liver fibrosis, steatosis, and hepatocellular carcinoma. Proc Natl Acad Sci U S A 2005, 102:3389-3394.

266. Anderberg C, Li H, Fredriksson L, Andrae J, Betsholtz C, Li X, Eriksson U, Pietras K: Paracrine signaling by platelet-derived growth factor-CC promotes tumor growth by recruitment of cancer-associated fibroblasts. Cancer Res 2009, 69:369-378.

267. Bandapalli OR, Macher-Goeppinger S, Schirmacher P, Brand K: Paracrine signalling in colorectal liver metastases involving tumor cell-derived PDGFC and hepatic stellate cell-derived PAK-2. Clin Exp Metastasis 2012 29:409-417
268. Li H, Fredriksson L, Li X, Eriksson U: PDGF-D is a potent transforming and angiogenic growth factor. Oncogene 2003, 22:1501-1510.

269. Furuhashi M, Sjöblom T, Abramsson A, Ellingsen J, Micke P, Li H, BergstenFolestad E, Eriksson U, Heuchel R, Betsholtz C, et al: Platelet-derived growth factor production by B16 melanoma cells leads to increased pericyte abundance in tumors and an associated increase in tumor growth rate. Cancer Res 2004, 64:2725-2733.

270. Hägglöf C, Hammarsten P, Josefsson A, Stattin P, Paulsson J, Bergh A, Östman A: Stromal PDGFRbeta expression in prostate tumors and nonmalignant prostate tissue predicts prostate cancer survival. PLoS One 2010, 5:e10747.

271. Paulsson J, Sjöblom T, Micke P, Pontén F, Landberg G, Heldin C-H, Bergh J, Brennan DJ, Jirström K, Östman A: Prognostic significance of stromal platelet-derived growth factor $\beta$-receptor expression in human breast cancer. Am J Pathol 2009, 175:334-341.

272. Kitadai Y, Sasaki T, Kuwai T, Nakamura T, Bucana CD, Fidler IJ: Targeting the expression of platelet-derived growth factor receptor by reactive stroma inhibits growth and metastasis of human colon carcinoma. Am J Pathol 2006, 169:2054-2065.

273. Yuzawa S, Kano MR, Einama T, Nishihara H: PDGFRß expression in tumor stroma of pancreatic adenocarcinoma as a reliable prognostic marker. Med Oncol 2012, 29:2824-2830.

274. Pietras K, Östman A, Sjöquist M, Buchdunger E, Reed RK, Heldin C-H, Rubin $\mathrm{K}$ : Inhibition of platelet-derived growth factor receptors reduces interstitial hypertension and increases transcapillary transport in tumors. Cancer Res 2001, 61:2929-2934.

275. Pietras K, Rubin K, Sjöblom T, Buchdunger E, Sjöquist M, Heldin C-H, Östman A: Inhibition of PDGF receptor signaling in tumor stroma enhances antitumor effect of chemotherapy. Cancer Res 2002, 62:5476-5484.

276. Falcon BL, Pietras K, Chou J, Chen D, Sennino B, Hanahan D, McDonald DM: Increased vascular delivery and efficacy of chemotherapy after inhibition of platelet-derived growth factor-B. Am J Pathol 2011, 178:2920-2930.

277. Tong RT, Boucher Y, Kozin SV, Winkler F, Hicklin DJ, Jain RK: Vascular normalization by vascular endothelial growth factor receptor 2 blockade induces a pressure gradient across the vasculature and improves drug penetration in tumors. Cancer Res 2004, 64:3731-3736.

278. Willett CG, Boucher Y, Di Tomaso E, Duda DG, Munn LL, Tong RT, Chung DC, Sahani DV, Kalva SP, Kozin SV, et al: Direct evidence that the VEGFspecific antibody bevacizumab has antivascular effects in human rectal cancer. Nat Med 2004, 10:145-147.

279. Kłosowska-Wardęga A, Hasumi Y, Burmakin M, Åhgren A, Stuhr L, Moen I, Reed RK, Rubin K, Hellberg C, Heldin C-H: Combined anti-angiogenic therapy targeting PDGF and VEGF receptors lowers the interstitial fluid pressure in a murine experimental carcinoma. PLoS One 2009, 4:e8149.

280. Gerber DE, Gupta P, Dellinger MT, Toombs JE, Peyton M, Duignan I, Malaby J, Bailey T, Burns C, Brekken RA, Loizos N: Stromal platelet-derived growth factor receptor a (PDGFRa) provides a therapeutic target independent of tumor cell PDGFRa expression in lung cancer xenografts. Mol Cancer Ther 2012, 11:2473-2482.

281. Kinoshita K, Nakagawa K, Hamada J, Hida Y, Tada M, Kondo S, Moriuchi T: Imatinib mesylate inhibits the proliferation-stimulating effect of human lung cancer-associated stromal fibroblasts on lung cancer cells. Int Oncol 2010, 37:869-877.

282. Catena R, Luis-Ravelo D, Anton I, Zandueta C, Salazar-Colocho P, Larzabal L, Calvo A, Lecanda F: PDGFR signaling blockade in marrow stroma impairs lung cancer bone metastasis. Cancer Res 2010, 71:164-174.

283. Shinagawa K, Kitadai $Y$, Tanaka M, Sumida T, Onoyama M, Ohnishi M, Ohara E, Higashi Y, Tanaka S, Yasui W, Chayama K: Stroma-directed imatinib therapy impairs the tumor-promoting effect of bone marrow-derived mesenchymal stem cells in an orthotopic transplantation model of colon cancer. Int J Cancer 2013, 132:813-823.

doi:10.1186/1478-811X-11-97

Cite this article as: Heldin: Targeting the PDGF signaling pathway in tumor treatment. Cell Communication and Signaling 2013 11:97. 